\title{
Diamonds and the Mantle Geodynamics of Carbon
}

\section{Deep Mantle Carbon Evolution from the Diamond Record}

\author{
STEVEN B. SHIREY, KAREN V. SMIT, D. GRAHAM PEARSON, \\ MICHAEL J. WALTER, SONJA AULBACH, FRANK E. BRENKER, HÉLÈNE BUREAU, \\ ANTONY D. BURNHAM, PIERRE CARTIGNY, THOMAS CHACKO, \\ DANIEL J. FROST, ERIK H. HAURI, DORRIT E. JACOB, STEVEN D. JACOBSEN, \\ SIMON C. KOHN, ROBERT W. LUTH, SAMI MIKHAIL, ODED NAVON, \\ FABRIZIO NESTOLA, PAOLO NIMIS, MEDERIC PALOT, EVAN M. SMITH, \\ THOMAS STACHEL, VINCENZO STAGNO, ANDREW STEELE, RICHARD A. STERN, \\ EMILIE THOMASSOT, ANDREW R. THOMSON, AND YAAKOV WEISS
}

\subsection{Introduction}

The importance of diamond to carbon in Earth is due to the fact that diamond is the only mineral and especially the only carbon mineral to crystallize throughout the silicate Earth from the crust to the lower mantle. To study diamond is to study deep carbon directly throughout Earth, allowing us to see the inaccessible part of the deep carbon cycle. By using the properties of diamond, including its ability to preserve included minerals, important questions relating to carbon and its role in planetary-scale geology can be addressed:

- What is the mineralogy of phases from Earth's mantle transition zone and lower mantle?

- What are the pressures and temperatures of diamond growth?

- What is the chemical speciation of recycled and deep carbon?

- What are the reactions that produce reduced carbon?

- What are the sources of carbon and its associated volatiles $\left(\mathrm{H}_{2} \mathrm{O}, \mathrm{CH}_{4}, \mathrm{CO}_{2}, \mathrm{~N}_{2}, \mathrm{NH}_{3}\right.$, and $\mathrm{S})$ ?

- How do these findings vary with global-scale geological processes?

- How have these processes changed over billions of years of geologic history?

Diamonds for scientific study are difficult to obtain and the nature of diamond presents special research challenges. Diamonds, whether they are lithospheric or sublithospheric (see the paragraph after next below), are xenocrysts in kimberlitic magma that travel a long path (as much as 150 to $>400 \mathrm{~km}$ !) during eruption to Earth's surface. On strict petrologic grounds, by the time a diamond reaches Earth's surface, there is little direct evidence that it is related to any neighboring diamond. However, the suites of diamonds that occur in close spatial association at Earth's surface in a mine may have similar physical characteristics and may also record similar pressure-temperature conditions and ages. If so, these features would suggest that the host kimberlite delivered a diamond suite to the surface from a spatially restricted mantle source hundreds of kilometers distant. Kimberlite magmas can 
transport some diamonds in mantle blocks that apparently disaggregate near the end of their upward journey. Nonetheless, each diamond and its inclusions is a case study unto itself until its association with other diamonds can be confirmed.

The Diamonds and Mantle Geodynamics of Carbon (DMGC) consortium was conceived early in the existence of the Deep Carbon Observatory (DCO) for the specific purpose of breaking down the traditional barriers to research on single diamonds and directing research toward global carbon questions. From the outset, the DMGC consortium focused on making cross-disciplinary research tools available, sharing samples so that more definitive results could be obtained, and enhancing intellectual stimulation across research groups so that new ideas would develop. The purpose of this chapter is to showcase results from the major collaborative research areas that have emerged within the DMGC consortium: (1) geothermobarometry to allow the depth of diamond crystallization and constraints on diamond exhumation to be determined (Section 5.2); (2) diamond-forming reactions, $\mathrm{C}$ and $\mathrm{N}$ isotopic compositions, and diamond-forming fluids to understand how diamonds form in the mantle (Section 5.3); (3) the sources of carbon either from the surface or within the mantle to provide information on the way carbon and other volatiles are recycled by global processes (Section 5.4); and (4) the mineralogy, trace element, and isotopic composition of mineral inclusions and their host diamonds to relate diamond formation to geologic conditions in the lithospheric and deeper convecting mantle (Section 5.5).

A general review and summary of diamond research can be obtained by consulting previous works. ${ }^{1-16}$ Much of this literature focuses on diamonds and the mineral inclusions that have been encapsulated when these diamonds crystallized in the subcontinental lithospheric mantle (SCLM). These so-called lithospheric diamonds can be classified as eclogitic or peridotitic (harzbugitic, lherzolitic, or websteritic) based on the composition of silicate or sulfide inclusions. ${ }^{10,16}$ Lithospheric diamonds crystallize at depths of around 100-200 km and temperatures of around $1160 \pm 100^{\circ} \mathrm{C} .{ }^{16}$ Peridotitic diamonds typically have restricted, mantle-like $\mathrm{C}$ isotopic compositions, whereas eclogitic diamonds have more variable and sometimes distinctly lighter $\mathrm{C}$ isotopic compositions. ${ }^{8}$ Lithospheric diamonds are likely to contain appreciable nitrogen (mostly Type I; 0-3830 at. ppm, median $=91$ at. $\mathrm{ppm}^{16}$ ). Their ages range from Cretaceous to Mesoarchean, but most are Proterozoic to Neoarchean. ${ }^{1,7,17}$ The study of lithospheric diamonds has led to advances in understanding of the stabilization of the continents and their mantle keels, the onset of plate tectonics, and the nature of continental margin subduction, especially in the ancient past.

In the last two decades, attention has turned to the study of diamonds whose inclusion mineralogies and estimated pressures of origin put them at mantle depths well below the lithospheric mantle beneath continents. These "sublithospheric" or so-called superdeep diamonds can occur at any depth down to and including the top of the lower mantle $(660-690 \mathrm{~km})$, but a great many crystallize in the mantle transition zone (e.g. $410-660 \mathrm{~km})^{9,12,18}$ at higher temperatures (between 100 and $400^{\circ} \mathrm{C}$ higher) ${ }^{19}$ than lithospheric diamonds. Unlike lithospheric diamonds, super-deep diamonds are not as easily classified as eclogitic or peridotitic. However, super-deep diamonds do carry mineral 
phases that are the high-pressure derivatives of basaltic and ultramafic precursors such as majorite or bridgmanite, respectively, ${ }^{12}$ so a petrologic parallel exists in super-deep diamonds with the eclogitic and peridotitic lithospheric diamond designation. Super-deep diamonds are typically low nitrogen (e.g. Type IIa or IIb) and display quite variable $\mathrm{C}$ isotopic compositions, even extending to quite light compositions (Section 5.4.2 and Ref. 20). Age determinations on super-deep diamonds are rare, but the few that exist ${ }^{21}$ support their being much younger than lithospheric diamonds - an expected result given the known antiquity of the continents and their attached mantle keels relative to the convecting mantle. The study of super-deep diamonds has led to advances in understanding of the deep recycling of elements from the surface (e.g. $\mathrm{H}_{2} \mathrm{O}, \mathrm{B}, \mathrm{C}$, and $\mathrm{S}$ ), the redox structure of the mantle, and the highly heterogeneous nature of the mantle transition zone.

Much of the research described in this chapter focuses on super-deep diamonds since the study of super-deep diamonds has the greatest relevance to the deep carbon cycle.

\subsection{Physical Conditions of Diamond Formation}

\subsubsection{Measuring the Depth of Diamond Formation}

An essential question is the depth at which a diamond forms. Geobarometry of diamonds based on the stability of their included minerals has provided important constraints on the deep carbon cycle. Application of these methods has yielded the whole range of depths from 110 to $150 \mathrm{~km}$, corresponding to the graphite-diamond boundary in the lithosphere, to over $660 \mathrm{~km}$, lying within the lower mantle. ${ }^{14,22-25}$ Thus, these studies have provided direct evidence for the recycling of surficial carbon to lower-mantle depths. Traditional geobarometric methods, however, have several limitations: they can only be applied to rare types of mineral inclusions; touching inclusions may re-equilibrate after diamond growth; non-touching inclusions may be incorporated under different conditions and may not be in equilibrium; and protogenetic inclusions ${ }^{26,27}$ may not re-equilibrate completely during diamond growth.

In order to avoid some of these drawbacks, alternative approaches that are independent of chemical equilibria are increasingly being explored. Elastic geobarometry is based on the determination of the residual pressure on the inclusion, $\mathrm{P}_{\text {inc }}$, which builds up on an inclusion when the diamond is exhumed to the surface as a result of the difference in the elastic properties of the inclusion and host. If these properties are known and the entrapment temperature is derived independently or its effect is demonstrably negligible, then the entrapment pressure can be calculated back from the $\mathrm{P}_{\text {inc }}$ determined at room conditions. The idea of using $\mathrm{P}_{\text {inc }}$ to calculate entrapment conditions is not new, ${ }^{28}$ but practical methods have recently been developed that allow more robust estimates of minerals with known elastic properties. ${ }^{29,30}$ In principle, elastic geobarometry can be applied to any inclusion in a diamond if: (1) the inclusion-diamond interaction is purely elastic, otherwise only minimum estimates can generally be obtained; (2) the geometry of the inclusion-host system is properly considered; and (3) mineral-specific calibrations are available to 
calculate $\mathrm{P}_{\text {inc }}$ from X-ray diffraction or micro-Raman spectroscopy data. Contrary to common practice, calibrations should take into account the effect of deviatoric stresses, which typically develop in inclusion-diamond systems upon exhumation. For example, Anzolini et al. ${ }^{31}$ showed that only an accurate choice of Raman peaks could provide reliable estimates for a $\mathrm{CaSiO}_{3}$-walstromite inclusion in diamond, yielding a minimum formation depth of $260 \mathrm{~km}$ and supporting $\mathrm{CaSiO}_{3}$-walstromite as a potential indicator of sublithospheric origin. The effect of the presence of fluid films around the inclusions, which has recently been documented in some lithospheric diamonds, ${ }^{32}$ still demands proper evaluation. In addition, the ability of diamond to deform plastically, especially under sublithospheric conditions, is well known, but methods to quantify any effects on elastic geobarometry are not available. Therefore, in many cases, only minimum estimates can be obtained. Nonetheless, we are now able to provide depth or minimum depth estimates for a number of new single-phase assemblages that would not be possible with more traditional methods. Future geobarometry of larger sets of diamonds, using both elastic and traditional approaches, will allow more comprehensive data to be gathered on the conditions for diamond-forming reactions and on the deep carbon cycle.

\subsubsection{Thermal Modeling of Diamond in the Mantle from Fourier-Transform Infrared Spectroscopy Maps}

The defects trapped in diamonds can be used to constrain estimates of the temperature that prevailed during the residence of a diamond in the mantle and can help constrain estimates of the return path of carbon to the surface. Pressure and temperature covary with depth in Earth, and the ability of the diamond lattice to record temperature history in its defect structure provides an additional independent constraint on estimates of mantle location. These measurements are therefore complementary to those on inclusions that can be used to determine the pressure and temperature conditions during the trapping of inclusions during diamond growth. The general concepts and calibration of a thermochronometer based on nitrogen defect aggregation are well established. ${ }^{33}$ The technique is based on the kinetics of aggregation of pairs of nitrogen atoms (called A centers) into groups of four nitrogen atoms around a vacancy (called B centers) and measurement of these defect concentrations using Fourier-transform infrared (FTIR) spectroscopy. The FTIR spectroscopy method has long been used as one of the standard characterization techniques for diamonds, mostly for whole stones, but also as FTIR spectroscopy maps showing the distribution of defect concentrations across diamond plates. ${ }^{34,35}$ Only recently has the full potential of FTIR spectroscopy for determining the thermal history of a diamond been recognized. The major recent developments have been: (1) improvements in the methods for acquiring and processing FTIR spectroscopy maps ${ }^{34}$; (2) a better understanding of the temperature history that is available from zoned diamonds ${ }^{36}$; and (3) unlocking the abundant information that is provided by the FTIR spectroscopy signal of platelets - planar defects created with $\mathrm{B}$ centers during nitrogen aggregation. ${ }^{37,38}$ 


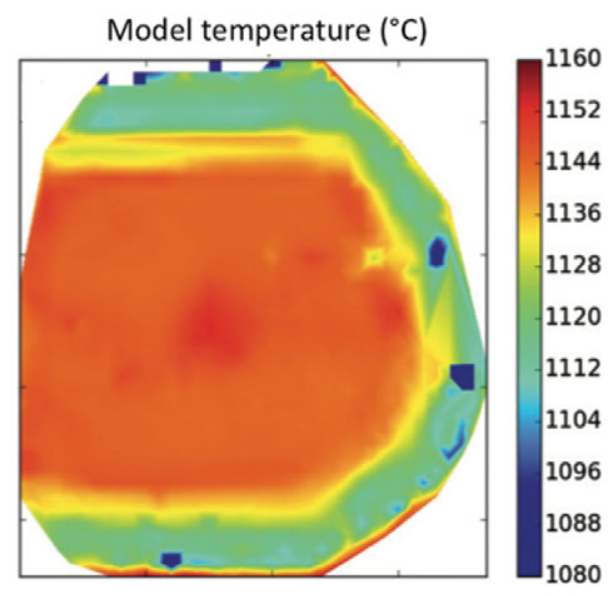

(a)

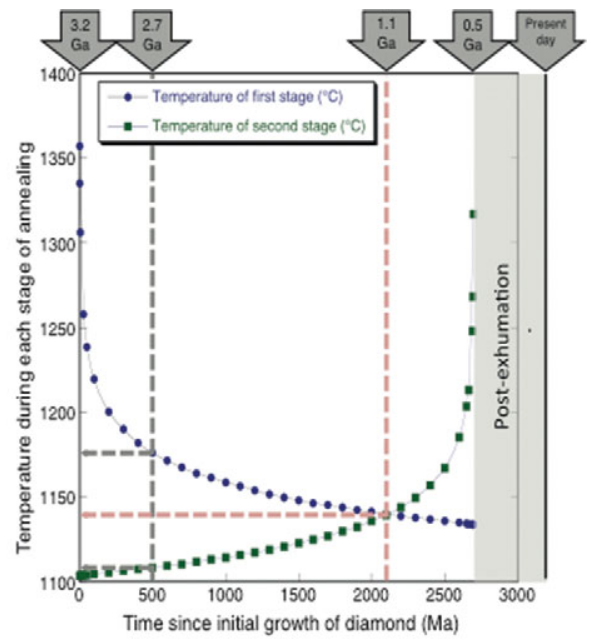

(b)

Figure 5.1 (a) Example of a map of "model temperatures" made up by automated fitting of several thousand FTIR spectra in a map of a diamond from Murowa, Zimbabwe. Model temperatures are calculated using a single assumed mantle residence time. The higher model temperatures in the core and lower model temperatures in the rim reflect a growth and annealing history with at least two stages. (b) Modeling the possible combinations of temperature and time that could explain the FTIR spectroscopy characteristics of a zoned diamond from Murowa. ${ }^{36}$

Figure 5.1a shows a map of "model temperatures" made up by automated fitting of several thousand FTIR spectra in a map of a diamond from Murowa, Zimbabwe. The higher temperatures in the core and lower temperatures in the rim reflect a growth and annealing history with at least two stages. The key idea is that the $\mathrm{N}$ aggregation in the rim only occurs during the second stage of annealing, but that $\mathrm{N}$ aggregation in the core occurs throughout the residence period of the diamond in the mantle (i.e. during both stages of annealing). Even if the date of rim growth is not known, there is an interplay between the temperatures of the two stages and the time of rim formation (Figure 5.1b). While these data provide a combination of time and temperature, if the dates of each stage of diamond formation are accurately known (by dating of inclusions) and the date of kimberlite eruption is known, the temperatures during the two stages can be determined. The model in Figure 5.1b assumes core growth at 3.2 Ga followed by a period of annealing, then rim growth and finally a second period of annealing. If a constant temperature prevailed throughout the history of the diamond's residence in the lithosphere, the ages of the two periods of growth are 3.2 and $1.1 \mathrm{Ga}$. If the earlier history of the diamond was hotter, the overgrowth must be older. Using this method, the mean temperature variation over very long (billion-year) timescales at a specific location in the lithosphere can be determined.

An alternative way to learn about the history of a diamond is to study the production and degradation of platelets. By comparing transmission electron microscopy and FTIR 
spectroscopy measurements on platelets, we now have a much better understanding of the meaning of the FTIR spectroscopy platelet peak characteristics (position, area, width, and symmetry) and how platelets evolve with thermal history. ${ }^{37,38}$ In addition to diamonds with regular platelet behavior and irregular, platelet-degraded behavior, we have identified a new class of sub-regular diamonds with anomalously small platelets that have experienced unusually low mantle temperatures (below about $1120^{\circ} \mathrm{C}$ ).

In summary, improvements in our understanding of the defects incorporated into diamonds will contribute to better quantitative models of carbon precipitation, carbon storage in the mantle as diamond, and carbon exhumation during continental tectonics. Indeed, advances in the correlation of spectral features with newly understood defect types may allow diamond to emerge as a prime mineral for studying the uplift and exhumation in the global tectonic cycle (e.g. Ref. 39).

\subsection{Diamond-Forming Reactions, Mechanisms, and Fluids}

\subsubsection{Direct Observation of Reduced Mantle Volatiles in Lithospheric and Sublithospheric Diamonds}

Some carbon in the deep Earth is not stored in crystalline silicates but as fluids such as highly mobile metallic and carbonatitic liquids or supercritical (also known as highdensity) $\mathrm{C}-\mathrm{H}-\mathrm{O}$ fluids. As diamond is thought to crystallize from these species by different mechanisms, its study becomes a key way to understand these carbon-bearing fluids. Reduced volatiles in diamonds have only recently been identified, ${ }^{40}$ although they have long been predicted. ${ }^{41}$ Observations of reduced volatiles in any mantle sample are rare because they must avoid oxidation in the shallow mantle and crust on the way to Earth's surface. Direct samples of these reduced volatiles are crucial to understanding the redox speciation of mantle fluids and melts since they influence both melt composition and physical properties such as solidus temperature, viscosity, and density. ${ }^{42,43}$

Experimental results and thermodynamic modeling of $\mathrm{C}-\mathrm{H}-\mathrm{O}$ fluids at pressure and temperature and oxygen fugacities $\left(f \mathrm{O}_{2}\right)$ relevant to the lithospheric mantle show that methane $\left(\mathrm{CH}_{4}\right)$ is stable at $2 \mathrm{log}$ units below the fayalite-magnetite-quartz buffer $\left(\Delta \log f \mathrm{O}_{2}\right.$ (fayalite-magnetite-quartz buffer $\left.(\mathrm{FMQ})\right)<-2$ ) and becomes the dominant $\mathrm{C}-\mathrm{H}-\mathrm{O}$ species at around $\Delta \log f \mathrm{O}_{2}$ (FMQ) 4.5. ${ }^{44,45}$ At diamond-stable pressures, the lithosphere should typically have $f \mathrm{O}_{2}$ between FMQ $=-2$ and FMQ $=-4,{ }^{46}$ and the implication is that metasomatic and diamond-forming fluids should also generally be reduced. $^{47}$

Due to their metasomatic origin from fluids with $\mathrm{CO}_{2}, \mathrm{CO}_{3}$, or $\mathrm{CH}_{4}$ as the dominant carbon species, ${ }^{48}$ diamonds are the ultimate tracers of carbon cycling into the mantle. Mantle $\mathrm{CH}_{4}$ has recently been directly detected for the first time in diamond samples from both the lithospheric and sublithospheric mantle. ${ }^{40,49}$ Diamond is the ideal carrier, since it shields any trapped reduced volatiles from oxygen exchange during its rapid transport to the surface. Analyses of reduced volatiles, along with any coexisting phases and the host 

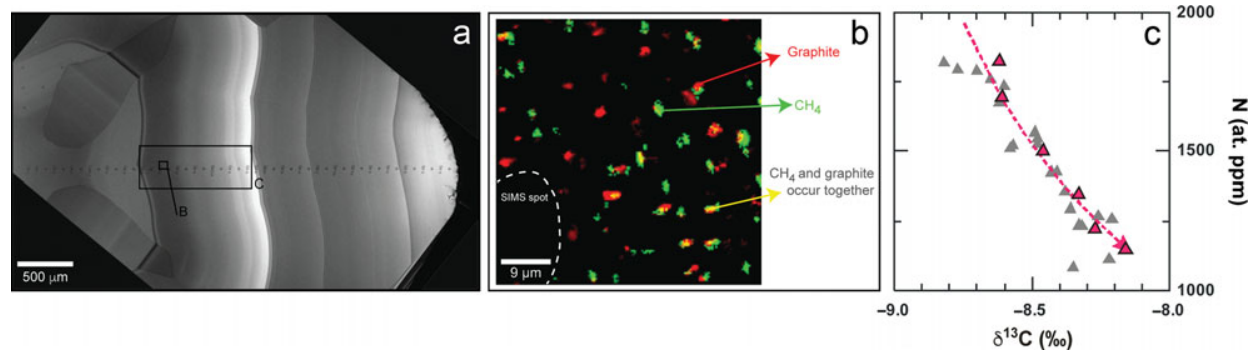

Figure 5.2 (a) Cathodoluminescence (CL) image of Marange diamond MAR06b, ${ }^{40}$ showing core-torim secondary ion mass spectrometry analytical spots. (b) Raman map showing distribution of graphite and $\mathrm{CH}_{4}$ micro-inclusions in a homogeneously grown cuboid zone. (c) Outwardly decreasing nitrogen content (atomic ppm) with increasing $\delta^{13} \mathrm{C}(\%)$ in this same cuboid growth zone (red) and other cuboid growth zones (gray). The modeled trend (red dashed line) is for a $\mathrm{CH}_{4}$ : $\mathrm{CO}_{2}$ ratio of $1: 1$ and assumes an initial $\delta^{13} \mathrm{C}$ for the fluid of $-7.4 \%$. For an assumed water content of $98 \mathrm{~mol} . \%$, the observed variation corresponds to $0.7 \%$ crystallization of the entire fluid (and $35 \%$ of the carbon in the fluid).

For details on modelling, see Stachel et al. ${ }^{51}$

diamonds, allow us to better understand the storage and transport of reduced volatiles into the mantle. These studies can also help us to evaluate whether methanogenesis occurs in the mantle ${ }^{50}$ or whether mantle $\mathrm{CH}_{4}$ has a subducted origin.

Lithospheric diamonds (depths $<200 \mathrm{~km}$ ) from Marange (Zimbabwe) are rare, mixedhabit diamonds that trap abundant inclusions in their cuboid sectors and also contain octahedral sectors that grew simultaneously. ${ }^{40}$ Confocal Raman imaging of the fastergrown cuboid sectors shows that they contain both crystalline graphite and $\mathrm{CH}_{4}$ inclusions (Figure 5.2). Both graphite and $\mathrm{CH}_{4}$ are evenly distributed throughout the cuboid sectors, usually but not always occurring together, a syngenetic texture that suggests that they cocrystallized along with diamond from the same C-H-O fluid. Clear octahedral sectors never contain graphite or $\mathrm{CH}_{4}$.

In fluid inclusion-free diamonds, core-to-rim trends in $\delta^{13} \mathrm{C}$ and $\mathrm{N}$ content have been (and probably should not have been) used to infer the speciation of the diamond-forming fluid. Outwardly decreasing $\delta^{13} \mathrm{C}$ with decreasing $\mathrm{N}$ content is interpreted as diamond growth from reduced fluids, whereas oxidized $\mathrm{CO}_{2}$ or carbonate-bearing fluids should show the opposite trends. Within the $\mathrm{CH}_{4}$-bearing sectors of Marange diamonds, however, such reduced trends are not observed. Rather, $\delta^{13} \mathrm{C}$ increases outwardly within a homogeneously grown zone that also contains $\mathrm{CH}_{4}$ (Figure 5.2). These contradictory observations can be explained through either mixing between $\mathrm{CH}_{4}$ - and $\mathrm{CO}_{2}$-rich end-members of hydrous fluids ${ }^{40}$ or through closed-system precipitation from an already mixed $\mathrm{CH}_{4}-\mathrm{CO}_{2}$ $\mathrm{H}_{2} \mathrm{O}$-maximum fluid. ${ }^{51}$ The relatively low $\delta^{13} \mathrm{C}$ value of the initial fluid (modeled at approximately $-7.4 \%$ ), ${ }^{51}$ along with positive $\delta^{15} \mathrm{~N}$ values (calculated using the diamond-fluid fractionation factor from Petts et al. ${ }^{52}$ ), suggests that the $\mathrm{CH}_{4}$-rich Marange diamond source fluids may in part have been subduction derived. 
Sublithospheric gem-quality monocrystalline diamonds from depths of between 360 and $750 \mathrm{~km}$ have also recently been found to contain inclusions with reduced volatile budgets. ${ }^{49}$ Specifically, iron- and nickel-rich metallic inclusions are consistently trapped along with $\mathrm{CH}_{4}$ (and $\mathrm{H}_{2}$ ) in large gem-quality monocrystalline diamonds. This suggests that $\mathrm{C}-\mathrm{H}-\mathrm{O}$ fluids in metal-saturated regions of the deep mantle are buffered to reduced compositions, either dissolved into metallic liquids or existing as $\mathrm{CH}_{4}$-rich fluids.

The key role of $\mathrm{CH}_{4}$ in the precipitation of diamond and its efficient transport through Earth's mantle has long been inferred on petrological grounds, ${ }^{53,54}$ but it is through these studies on Zimbabwe and sublithospheric diamonds that we now have the first observations of this important fluid species. Further investigation of fluid species in diamonds are needed: (1) to establish the frequency of the involvement of reduced volatiles in diamond formation; and (2) to differentiate the geological environments where transport of carbon and diamond precipitation involves $\mathrm{CH}_{4}$-rich fluids ${ }^{55}$ versus carbonate-rich fluids or melts. ${ }^{56,57}$

\subsubsection{Redox-Neutral Diamond Formation and Its Unexpected Effect on Carbon Isotope Fractionation}

Using models of diamond crystallization from fluids of specific composition, the variation of carbon isotopic compositions across a diamond crystal can be used to estimate fluid composition, interaction with fluid-hosting wall rock, and C source characteristics. This approach has been applied most successfully to lithospheric diamonds. Studies of garnet peridotite xenoliths ${ }^{46,47}$ demonstrate that subcratonic lithospheric mantle typically lies on the reducing side of the $f \mathrm{O}_{2}$ of the EMOD buffer (enstatite + magnesite $\rightarrow$ olivine + diamond: the transition from carbonate- to diamond-bearing peridotite), but well above that of the IW buffer (iron $\rightarrow$ wüstite: where native iron becomes stable). Consequently, in the deep lithospheric mantle, carbon will generally be stored as diamond rather than carbonate or carbide. From the study of mineral inclusions in diamond, we know that strongly depleted harzburgite and dunite are the principal ( $\sim 56 \%)$ diamond substrates in lithospheric mantle. On this basis, we set out to address two fundamental questions: (1) in what form is carbon transported to lithospheric diamond substrates? And (2) what exactly is the process that drives the conversion of carbon-bearing fluid species into elemental carbon?

Luth and Stachel ${ }^{47}$ modeled that $<50 \mathrm{ppm} \mathrm{O}_{2}$ has to be removed from or added to depleted cratonic peridotite to move its oxidation state from the EMOD to the IW buffer (or vice versa). This extremely low buffering capacity of cratonic peridotites has two important implications: (1) the redox state of subcratonic lithospheric mantle is fluid buffered and, consequently, studies of peridotite xenoliths can only reveal the redox state of the last fluid with which they interacted; and (2) redox reactions buffered by depleted cratonic peridotite cannot explain the formation of large diamonds or large quantities of diamonds (per volume unit of peridotite).

At the typical $f_{2}$ conditions of diamond-stable cratonic peridotite $\left(\Delta \log f \mathrm{O}_{2}(\mathrm{FMQ})=\right.$ -1.5 to -3.5$)$, C-H-O fluids will be water rich (90-99 mol.\%) with minor amounts of $\mathrm{CH}_{4}$ 
and $\mathrm{CO}_{2}$. During cooling or ascent along a geotherm (cooling plus decompression), such near-water-maximum fluids precipitate diamond isochemically, without the need for oxygen exchange with their peridotitic wall rocks. ${ }^{47,58}$ At conditions just below the EMOD buffer $\left(\Delta \log f \mathrm{O}_{2}(\mathrm{FMQ})=-1.5\right.$ to -2.4 , at $5 \mathrm{GPa}$ and $\left.1140^{\circ} \mathrm{C}\right)$, diamond precipitation can occur by the oxygen-conserving reaction:

$$
\mathrm{CO}_{2}+\mathrm{CH}_{4} \rightarrow 2 \mathrm{C}+2 \mathrm{H}_{2} \mathrm{O}
$$

At more reducing conditions $\left(\Delta \log f \mathrm{O}_{2}(\mathrm{FMQ}) \leq-3\right)$, ascending fluids may precipitate diamond via a second redox-neutral reaction:

$$
2 \mathrm{C}_{2} \mathrm{H}_{6} \rightarrow 3 \mathrm{CH}_{4}+\mathrm{C}
$$

These modes of isochemical diamond precipitation require that fluids remain relatively pure (i.e. that progressive dilution of the fluid through addition of a melt component does not occur). For water-maximum fluids ascending along a normal cratonic geotherm $\left(40 \mathrm{~mW} / \mathrm{m}^{2}\right),{ }^{59}$ this condition is only met for harzburgite and dunite, whereas the higher melting temperatures of peridotite in the presence of more reducing fluids permits the reaction in Eq. (5.2) to occur in lherzolites as well. ${ }^{58}$

In such fluid-buffered systems, the fractionation of carbon isotopes during diamond growth occurs in the presence of two dominant carbon species in the fluid: either $\mathrm{CH}_{4}+\mathrm{CO}_{2}$ or $\mathrm{CH}_{4}+\mathrm{C}_{2} \mathrm{H}_{6}$. The equations to model Rayleigh isotopic fractionation in these multi-component systems (RIFMS) were developed by Ray and Ramesh ${ }^{60}$ and applied to the geologically likely case (based on xenolith $f \mathrm{O}_{2}$ measurements) of diamond precipitation from ascending or cooling near-water-maximum fluids (reaction 1). ${ }^{51}$

Calculations revealed unexpected fundamental differences relative to diamond crystallization from a single carbon fluid species:

(1) Irrespective of which carbon species $\left(\mathrm{CH}_{4}\right.$ or $\left.\mathrm{CO}_{2}\right)$ dominates the fluid, diamond crystallization from mixed $\mathrm{CH}_{4}-\mathrm{CO}_{2}$ fluids will always lead to minor $(<1 \%$ ) enrichment in ${ }^{13} \mathrm{C}$ as crystallization proceeds. In contrast, diamond precipitation through wall rock-buffered redox reactions from a fluid containing only a single carbon species can result in either progressive ${ }^{13} \mathrm{C}$ enrichment $\left(\mathrm{CO}_{2}\right.$ or carbonate fluids) or ${ }^{13} \mathrm{C}$ depletion $\left(\mathrm{CH}_{4}\right.$ fluids $)$ in diamond. These two contrasting models of diamond formation can be tested through $\delta^{13} \mathrm{C}-\mathrm{N}$ content profiles in individual diamonds as the mixed fluid model predicts that zoning profiles should be characterized by progressive ${ }^{13} \mathrm{C}$ enrichments, whereas the single fluid redox model predicts both ${ }^{13} \mathrm{C}$ enrichments and depletions, depending on whether the fluids are oxidized or reduced. Notably, the available zoning profile data are more consistent with the mixed fluid model in that coherent trends in $\delta^{13} \mathrm{C}$ values almost invariably involve rimward enrichments in ${ }^{13} \mathrm{C}$ and total variations within individual growth zones (i.e. zones precipitated from a single fluid pulse) are generally small $(<1 \%$ ).

(2) Because all mantle-derived fluids should have mantle-like $\delta^{13} \mathrm{C}$ values near $-5 \%$ irrespective of their redox state, fluid speciation exerts the principal control on 
diamond $\delta^{13} \mathrm{C}$ values. For example, the $\delta^{13} \mathrm{C}$ value of the first diamond precipitated from a relatively oxidized $\mathrm{CO}_{2}-\mathrm{CH}_{4} \mathrm{H}_{2} \mathrm{O}$ fluid in which $\mathrm{CO}_{2}$ is the dominant fluid carbon species $\left(\mathrm{CO}_{2} /\left[\mathrm{CO}_{2}+\mathrm{CH}_{4}\right]=0.9\right)$ will be $3.7 \%$ lower than the first diamond crystallized from a reduced mixed fluid in which $\mathrm{CH}_{4}$ is the dominant fluid carbon species $\left(\mathrm{CO}_{2} /\left[\mathrm{CO}_{2}+\mathrm{CH}_{4}\right]=0.1\right)$. Accordingly, the observed tight mode of peridotitic diamonds worldwide at $\delta^{13} \mathrm{C}$ of $-5 \pm 1 \%$ requires that $\mathrm{CH}_{4}$ generally constitutes $\geq 50 \%$ of the carbon species in peridotitic diamond-forming fluids.

The RIFMS equations were applied to $\mathrm{CH}_{4}$-bearing Marange diamonds (Figure 5.2) to model their in situ stable isotope and nitrogen content data. ${ }^{40}$ Application of Eq. (5.1) allowed us to perfectly match the observed covariations in $\delta^{13} \mathrm{C}-\delta^{15} \mathrm{~N}-\mathrm{N}$ content and at the same time explain the previously counterintuitive observation of progressive ${ }^{13} \mathrm{C}$ enrichment in diamonds (Figure 5.2) that appear to have grown from a fluid with $\mathrm{CH}_{4}$ as the dominant carbon species.

Importantly, the observation of $\mathrm{CH}_{4}$ in Marange diamonds (Section 5.3.1) along with detailed in situ isotope analyses ${ }^{40}$ have allowed us to confirm the important role of $\mathrm{CH}_{4}$-rich fluids in worldwide peridotitic diamond formation. At this time, in situ data on carbon and nitrogen isotope and $\mathrm{N}$ content zoning profiles across diamond plates are still fairly scarce. Future research and the acquisition of many more isotopic profiles across peridotitic diamonds is needed to test whether water-maximum fluids are indeed the prevalent way for peridotitic diamonds to form.

\subsubsection{Progress in Understanding Diamond-Forming Metasomatic Fluids}

Gem-quality monocrystalline diamond is often devoid of fluid inclusions, and so the best samples of C-rich diamond-forming fluids are those trapped by fast-growing, so-called fibrous diamond. Here, millions of microinclusions (normally $0.2-0.5 \mu \mathrm{m}$ in size) populate cuboid diamonds, internal fibrous zones of octahedral diamonds, or an overgrowth of a fibrous 'coat' around a preexisting diamond. The microinclusions carry a secondary mineral assemblage and a residual low-density hydrous fluid, ${ }^{61}$ which at mantle temperatures constitute a uniform high-density fluid (HDF; either a melt or a high-density supercritical $\mathrm{C}-\mathrm{H}-\mathrm{O}$ fluid). The major elements define four compositional end-members (Figure 5.3): saline HDFs rich in $\mathrm{Cl}, \mathrm{K}, \mathrm{Na}$, water, and carbonate; high-Mg carbonatitic $\mathrm{HDF}$ rich in $\mathrm{Mg}, \mathrm{Ca}, \mathrm{Fe}, \mathrm{K}$, and carbonate; and a continuous array between a low-Mg carbonatitic end-member rich in $\mathrm{Ca}, \mathrm{Fe}, \mathrm{K}, \mathrm{Mg}$, and carbonate and a silicic end-member rich in $\mathrm{Si}, \mathrm{K}, \mathrm{Al}, \mathrm{Fe}$, and water. ${ }^{62}$ The incompatible trace elements are highly enriched in all HDFs, reaching levels of $\sim 1000$ times the primordial mantle concentrations, and they are characterized by two main trace element patterns: one with alkali and high field strength element depletions and large ion lithophile element (LILE) enrichments similar to calcalkaline magmas and continental rocks; and the other with lower LILE abundances and smoother overall patterns similar to oceanic basalts. ${ }^{63,64}$ Radiogenic isotopic studies of $\mathrm{Sr}, \mathrm{Nd}$, and $\mathrm{Pb}$ tracers from HDFs are very scarce; nevertheless, the 

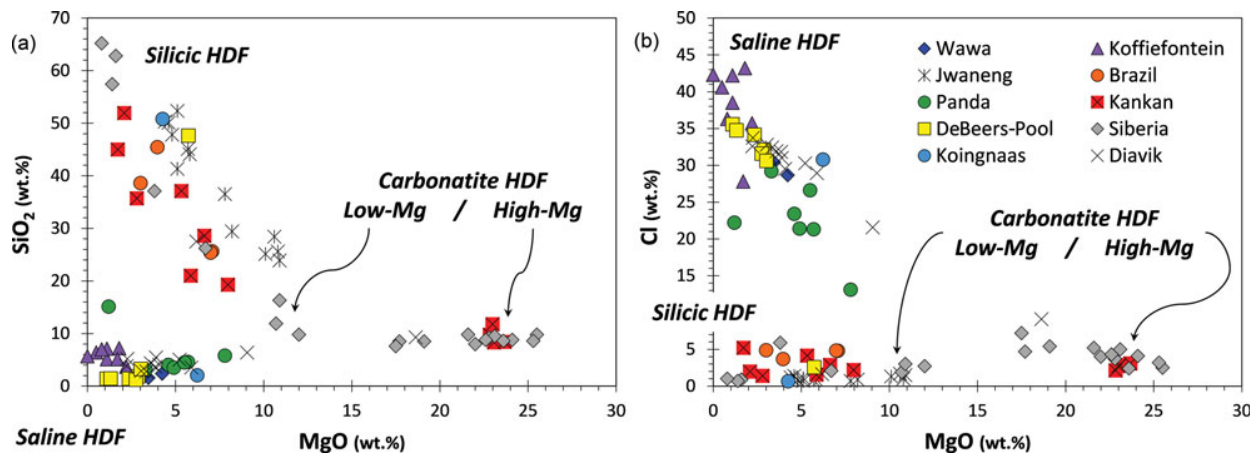

Figure 5.3 ( $\mathrm{a}$ and $\mathrm{b}$ ) $\mathrm{SiO}_{2}$ and $\mathrm{Cl}$ versus $\mathrm{MgO}$ content of $\mathrm{HDF}$ microinclusions in 89 fibrous diamonds from different lithospheric provinces (in wt.\% on a water- and carbonate-free basis). The high-Mg carbonatitic compositions are close to experimental near-solidus melts of carbonateperidotite, while the low-Mg carbonatitic to silicic HDFs form an array that is close in composition to experimentally produced fluids/melts in the eclogite + carbonate \pm water system. ${ }^{62,63,65-67}$ The saline HDF end-members have been related to fluids derived from seawater-altered subducted slabs. ${ }^{68}$

Data: DeBeers-Pool, Koingnaas, and Kankan from Weiss et al. ${ }^{62,69}$ Koffiefontein from Izraeli et al.; ${ }^{70}$ Brazil from Shiryaev et al. ${ }^{71}$ Diavik and Siberia from Klein Ben-David et al. ${ }^{72,73}$ Jwaneng from Schrauder and Navon, ${ }^{74}$ Panda from Tomlinson et al. ${ }^{75}$ Wawa from Smith et al. ${ }^{76}$

available data indicate their derivation from sources varying between the "depleted" convecting mantle and ancient incompatible element-enriched lithosphere (including recycled old continental crust $^{65}$ ).

As a rule, the composition of HDF microinclusions in an individual fibrous diamond is homogenous, with only a handful out of the 250 fibrous diamonds analyzed to date showing conspicuous radial (core-to-rim) changes. ${ }^{71}$ These diamonds revealed correlative variations in hydrous silicic fluids films around mineral inclusions ${ }^{32}$ and saline and carbonatitic HDF microinclusions in octahedral diamonds ${ }^{77}$ and in twinned crystals $\left(\right.$ macles $^{78}$ ). Together, these similarities suggest that many lithospheric diamonds could have formed from the four carbonate-bearing HDF end-members known from fibrous diamonds. These HDF fluids provide another growth mechanism that is different from the mechanism by which lithospheric diamonds form from non-carbonate-bearing fluids (see Sections 5.3.1 and 5.3.2).

Diamond formation is a by-product of mantle metasomatism, whereby HDFs migrate through and react with different mantle reservoirs. Their entrapment in the diamond gives us a unique glance at the initial stages of melting and at the enigmatic mantle process known as metasomatism. A strong connection exists between high-Mg carbonatitic HDFs and a carbonated peridotite, indicating that the diamond grew from carbon supplied by the HDFs. Also, the origins of silicic and low-Mg carbonatitic HDFs have been related to the melting of hydrous carbonated eclogites. ${ }^{65,67}$ On the other hand, fibrous diamonds generally make up less than a few percent of a mine's production, ${ }^{2}$ and differences in the 
textures, nitrogen aggregations, diamond ages, and the range of carbon isotopic compositions between fibrous and monocrystalline gem-quality diamonds mean that further work is needed to establish whether HDFs are responsible for the formation of all types of diamonds. Accumulating evidence indicates the involvement of HDFs in the growth of many monocrystalline diamonds - the most abundant type of diamond. The age difference between monocrystalline and fibrous diamonds was bridged by finding fibrous diamonds of Archean age, ${ }^{76}$ as well as fibrous diamonds with aggregated nitrogen $(25-70 \%$ $\mathrm{B}$ centers ${ }^{79}$ ). The interaction of HDFs with depleted garnets was shown to closely produce sinusoidal rare earth element (REE) patterns, ${ }^{62}$ which are one of the primary features of harzburgitic garnet inclusions in monocrystalline diamonds. ${ }^{10}$ The deep mantle source of saline HDFs has for many years remained ambiguous, until recently, when the first conclusive trace element and $\mathrm{Sr}$ isotopic fingerprints indicated that they are derived from seawater-altered subducted slabs. ${ }^{68}$ Moreover, clear chemical evolutionary trends in these Northwest Territories Canadian diamonds identify saline HDFs as parental to in situforming carbonatitic and silicic melts in the deep continental lithosphere. These advances open a new window on understanding the history of magmatism and metasomatism in the deep SCLM and their relationship to carbon and water mobility and diamond formation.

\subsection{Sources of Carbon and Recycling of Volatiles}

\subsubsection{Atmospheric and Biotic Recycling of Sulfur into the Mantle}

An important way to trace potential carbon sources in the deep carbon cycle is by using the petrogenesis of mineral inclusions in diamond. Iron-nickel-copper sulfides represent the most common type of mineral enclosed in diamonds. This overabundance of sulfide inclusions in diamonds compared with silicates suggests that a genetic link exists between sulfides and diamonds, but the exact nature of this relationship remains unclear.

Sulfide inclusion mineralogy implies at least two distinct origins for these sulfides, with Ni-rich specimens akin to peridotitic affinity and, more frequently, Ni-poor specimens that originate from a mafic crustal rock. Re/Os studies have provided robust evidence that sulfide inclusion compositions evolved with age. ${ }^{17}$ Sulfides older than $3 \mathrm{Ga}$ are all peridotitic, while eclogitic specimens prevail from the Mesoarchean until the Proterozoic. They display a discrete age distribution with at least one major age peak coeval with continental collision, which is well characterized in the Kaapvaal craton. These observations indicate irreversible changes in crust/mantle dynamics, with episodic subduction events starting ca. $3 \mathrm{Ga}$ that would have driven crustal sulfur into the cratonic keel. ${ }^{80}$

This scenario has major implications for the global budget of volatile elements and its evolution through time. In particular, the flux linking the shallow crust (which is a major sink of volatiles) and the mantle is a key parameter because it allows the recycling of light elements $(\mathrm{C}, \mathrm{O}, \mathrm{H}, \mathrm{N}, \mathrm{S})$ and thus partially controls the deep Earth budget.

Unlike carbon or oxygen, for which fractionated isotopic compositions can lead to ambiguous interpretation due to high-temperature fractionation processes ${ }^{81}$ or perturbation 
by mantle metasomatism, ${ }^{82} \mathrm{~S}$ isotopic systematics provides a unique way to assess the contribution of Archean surficial reservoirs in mantle rocks. ${ }^{83}$ Sulfur is present in all of the external envelopes of Earth (ocean, atmosphere, and biosphere). It participates in many chemical (biotic and abiotic) and photochemical reactions. Large variations of $\delta^{34} \mathrm{~S}$ in sedimentary rocks are mainly attributed to microbe-mediated sulfur metabolisms. On the other hand, in the Archean atmosphere, photochemical reactions involving UV light induced sulfur mass-independent fractionation (MIF). Photochemical products - elemental sulfur and sulfate aerosols - carried anomalous ${ }^{33} S$-enrichment $\left(\Delta^{33} S>0 \%\right)$ and depletion $\left(\Delta^{33} S<0 \%\right.$ ), respectively. Both species have been transferred to seawater and then preserved as two independent isotopic pools in chemical sediments (banded iron formations and black shales) or hydrothermally altered oceanic crust older than 2.4 Ga. MIF sulfur anomalies ceased sharply at the Archean/Proterozoic boundary as a consequence of UV screening by ozone. Thus, multiple $\mathrm{S}$ isotopic systematics is a robust tracer of the Archean surficial sulfur, ${ }^{83}$ but can also be used to track the fate of specific sedimentary pools.

Pioneering studies of $\mathrm{S}$ isotopes in sulfide inclusions reported departure from mantle composition and concluded that altered oceanic crust ${ }^{84}$ or sediments ${ }^{85}$ were recycled in the diamond growth environment. Multiple sulfur isotope measurements $\left(\delta^{33} \mathrm{~S}, \delta^{34} \mathrm{~S}\right)$ provide a more complete assessment of the recycled sulfur pools. ${ }^{83,86}$ In addition to a wide range of $\delta^{34} \mathrm{~S}\left(-9 \% 0<\delta^{34} \mathrm{~S}<3.4 \%\right.$ ) , eclogitic sulfide inclusions from the Orapa and Jwaneng diamonds carry MIFs that are mostly positive $\left(-0.5 \% \circ<\Delta^{33} \mathrm{~S}<1 \%\right)$. While the most anomalous sulfur isotopic compositions match the sulfur compositional trend produced by photochemical reactions with $220-\mathrm{nm}$ radiation ${ }^{87}$ previously found in Archean sediments, some ${ }^{34} \mathrm{~S}$-depleted specimens require additional fractionation, most likely related to biologic activity (Figure 5.4). By comparison, peridotitic sulfides from the Slave and Kaapvaal cratons $^{86,98}$ do not carry significant $\mathrm{MIF}\left(\Delta^{33} \mathrm{~S}\right.$ from -0.12 to $0.19 \%$ ). These results provide compelling evidence that MIF $\mathrm{S}$ isotopic signatures are not produced by hightemperature processes in the mantle, but indubitably reflect an input of chemical sediments from the surface to the diamond growth region.

Geologic evidence indicates that cratonic keels have been isolated early from the convecting mantle. This is consistent with the absence of $\Delta^{33} \mathrm{~S}$ anomalies in mid-ocean ridge basalt (MORB; Figure 5.4) reported by Labidi et al. ${ }^{89,90}$ Surprisingly, however, two independent studies on sulfides from ocean island basalt $(\mathrm{OIB})^{91}$ have reported small but significant negative $\Delta^{33} \mathrm{~S}$ anomalies (down to $-0.8 \%$ ) correlated with strictly negative $\delta^{34} \mathrm{~S}$ (Figure 5.4). In both Pitcairn (enriched mantle reservoir 1 (EM1)) and Mangaïa (high$\mu$ mantle reservoir (HIMU)) samples, these trends match the composition previously reported for sulfides from hydrothermal barite veins in altered oceanic crust. ${ }^{93,94}$ Accordingly, these studies indicate that deep mantle heterogeneities inherited from seawater Archean sulfates have been preserved over billions of years. It is worth noting that negative anomalies are underrepresented in the sedimentary record. One of the most exciting hypotheses coming along with the presence of negative $\Delta^{33} \mathrm{~S}$ in some OIB is that part of the missing surficial sulfur could be stored in the deep mantle. ${ }^{95}$ 


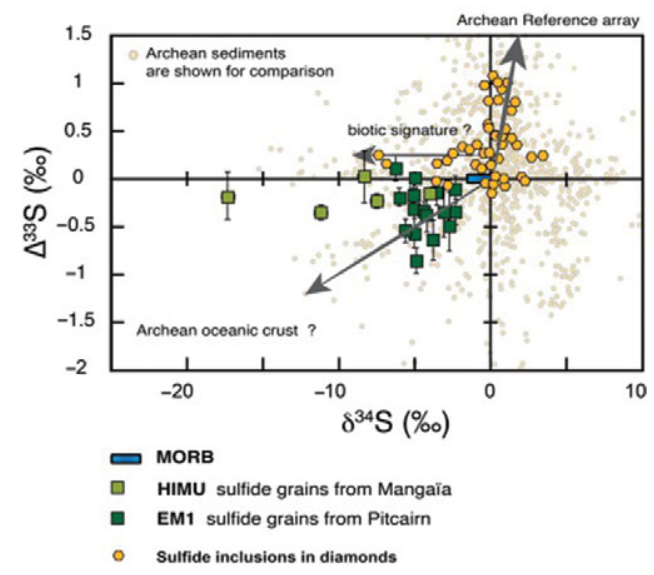

Figure $5.4 \Delta^{33} \mathrm{~S}(\%)$ versus $\delta^{34} \mathrm{~S}$ in mid-ocean ridge basalt (MORB; blue rectangle $\left.{ }^{87,89}, 90\right)$, sulfide inclusions in diamonds (yellow hexagons ${ }^{83,86}$ ), and sulfides from high- $\mu$ mantle reservoir (HIMU) ocean island basalt (OIB; Mangaïa, ${ }^{91}$ light green squares) and enriched mantle reservoir 1 (EM1) OIB (Pitcairn, ${ }^{92}$ dark green squares). While MORB are homogeneous and devoid of MIF, sulfides from SCLM and from some OIB contain the relict of Archean surficial sulfur. Sulfide inclusion compositions are best explained by a combination of atmospheric and biotic effect and resemble what has been previously observed in Archean chemical sediments. Sulfide in OIB carry negative $\Delta^{33} \mathrm{~S}$ together with negative $\delta^{34} \mathrm{~S}$, as previously observed in sulfides from altered oceanic crust.

The data obtained so far on mantle samples tend to indicate that the Archean surficial components recycled in the SCLM differ from those found in some OIB. Additional data are required to confirm this view. The relative abundance of the minor isotope of sulfur, ${ }^{36} \mathrm{~S}$, is also affected by both mass-dependent reactions (related to microbial cycling; e.g. Ono et al. ${ }^{96}$ ) and mass-independent atmospheric reactions that lead to variations of $\delta^{34} \mathrm{~S}$ and $\Delta^{33} \mathrm{~S}$. In the future, studying covariations of $\Delta^{33} \mathrm{~S}$ and $\Delta^{36} \mathrm{~S}$ may help to provide a more complete assessment of the recycled sulfur pools and ultimately add new constraints upon crust/mantle dynamics.

\subsubsection{Carbon and Nitrogen Cycling into the Mantle Transition Zone}

Studies of the carbon and nitrogen isotopic composition of diamonds represent an opportunity to examine volatile migration within the transition zone (410-660 km depth), a key region within Earth's interior that may be the main host for recycled material. Seismology and mineral physics show the tendency of subducted slabs to pond at the lower mantle transition zone boundary at $\sim 660 \mathrm{~km}$ depth within a region where diamonds capture rare inclusions of majorite garnet ${ }^{97}$ and assemblages comprising Ca-rich inclusions (CaSiperovskite, -walstromite, -larnite, -titanite). ${ }^{98}$ These rare diamonds principally originate from four localities: the Juína area in Brazil, Kankan in Guinea, and Monastery and Jagersfontein in South Africa. 
Brazilian diamonds with majorite inclusions exhibit carbon $\left(\delta^{13} \mathrm{C}=-10.3 \pm 5.5 \%, 1 \sigma\right.$; Figure 5.5 $\left.\mathrm{a}^{20,21,81,99-104}\right)$ and nitrogen isotope compositions $\left(\delta^{15} \mathrm{~N}=+0.4 \pm 2.9 \%, 1 \sigma\right.$; Figure 5.5b) well outside of the current mantle range $\left(\delta^{13} \mathrm{C}=-5 \pm 3 \%\right.$ and $\delta^{15} \mathrm{~N}=-5 \pm$ $4 \%$ ). Most likely, these diamond isotopic compositions record subduction-related carbon and nitrogen. ${ }^{101}$ The partial melting of former carbonated oceanic crust in the transition zone may produce carbonatitic melts, and the interaction of these melts with ambient convecting mantle may be responsible for the formation of many/most mantle transition zone diamonds and their inclusions (Figure 5.5c). ${ }^{56}$

Some Brazilian diamonds with super-deep Ca-rich assemblages are thought to derive from even greater depth, at the transition zone-lower mantle boundary. ${ }^{18}$ These diamonds with distinct carbon isotope compositions $\left(\delta^{13} \mathrm{C}=-5.9 \pm 3.7 \%\right.$; Figure 5.5a) that overlap with the main mantle range are suggested to originate either from homogenized subducted sediments (composed of $80 \%$ carbonate and $20 \%$ organic carbon) or mantle-related fluids from the convecting mantle (i.e. non-primordial; Figure 5.5c).

The carbon isotope compositions of Kankan diamonds with majorite- and with Casilicate inclusions are distinct from Brazilian samples by being ${ }^{13} \mathrm{C}$ enriched, with an overall $\delta^{13} \mathrm{C}$ of $0.3 \pm 2.2 \%$, outside the mantle range (Figure 5.5a). ${ }^{107,108}$ This carbon isotopic signature is consistent with derivation from subducted carbonate with no/little former organic carbon involved. The identification of carbonate inclusions in ultra-deep diamonds indicates that carbonate may be efficiently transported deep into the mantle. ${ }^{98}$ The positive $\delta^{15} \mathrm{~N}$ values of transition-zone diamonds from Kankan also strongly support a subduction origin. Modeling of the local covariations of $\delta^{13} \mathrm{C}-\delta^{15} \mathrm{~N}-\mathrm{N}$ compositions within individual diamonds indicates that they grew from parental fluids involving both oxidized (majority) and reduced (minority) fluids, ${ }^{107}$ highlighting the likely heterogeneity of the transition zone (Figure 5.5c).

Diamonds from Monastery and Jagersfontein containing majorite inclusions exhibit extremely depleted $\delta^{13} \mathrm{C}$ values of $-16.7 \pm 1.2 \%$ and $-19.7 \pm 2.1 \%$, respectively, and strictly positive $\delta^{15} \mathrm{~N}$ values (Figure 5.5a), which are again consistent with subducted material. ${ }^{106}$ The relatively low nitrogen contents $(<55$ at. ppm) of the host diamonds together with the positive chondrite-normalized REE slopes and high $\delta^{18} \mathrm{O}$ values of the majorite inclusions are consistent with the formation of these diamonds within hosts that originated from hydrothermally altered basaltic protoliths. The preferred mechanism to form these diamonds is by dissolution and re-precipitation (Figure 5.5c), where subducted metastable graphite would be converted into an oxidized or reduced species during fluidaided dissolution, before being re-precipitated as diamond. ${ }^{109}$ In this situation, carbon remains in the subducting slab and is locally redistributed to form sublithospheric diamonds beneath the Kaapvaal Craton (Figure 5.5c).

The carbon and nitrogen isotopic signatures of transition zone diamonds worldwide indicate that they likely crystallized from fluids derived from subducted material, illustrating the deep cycling of surficial carbon and nitrogen into and through the transition zone. Carbon and nitrogen seem to be efficiently retained in the oceanic lithosphere during subduction, prior to being locally mobilized in the transition zone to form diamonds. 


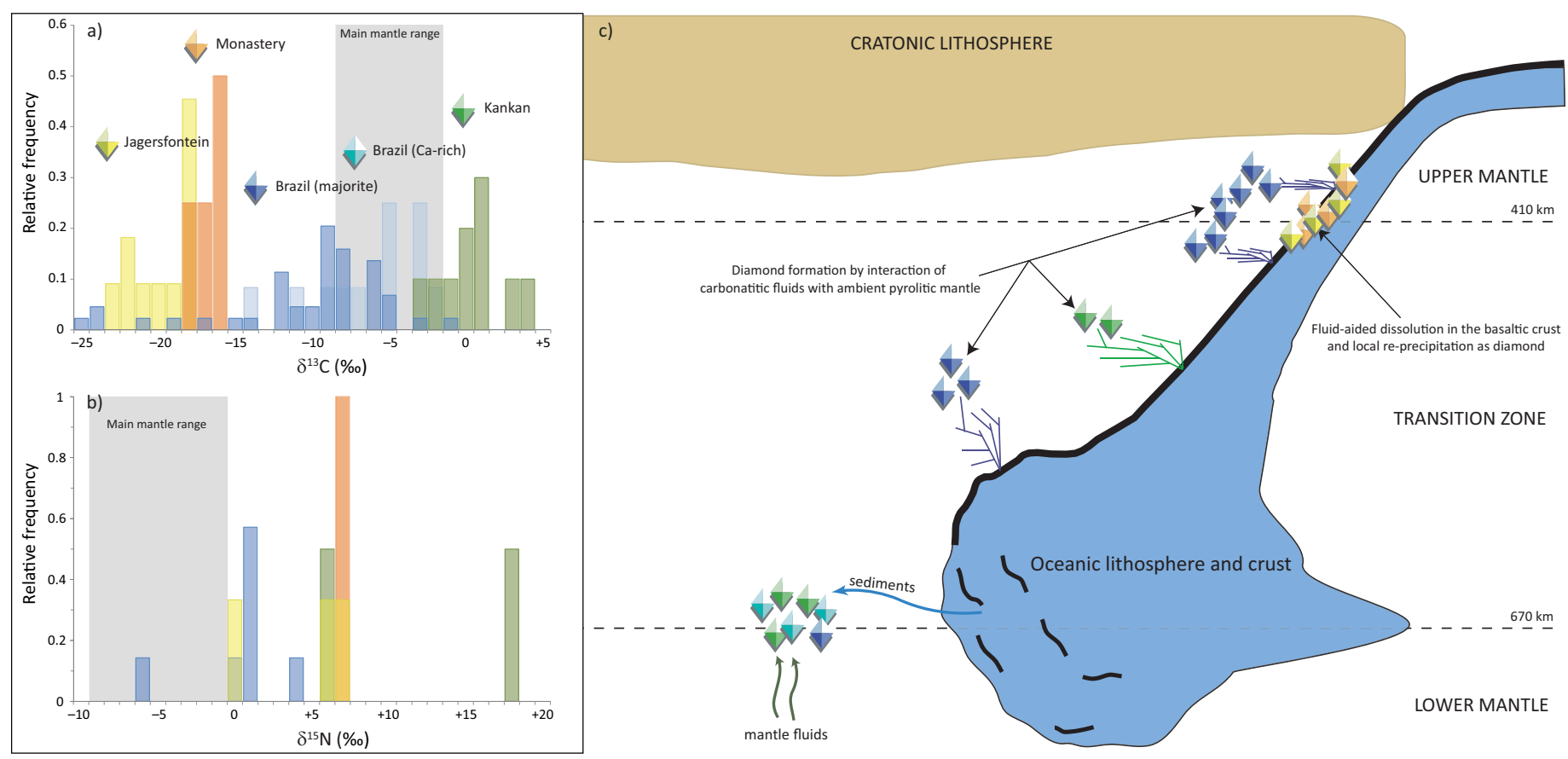

Figure 5.5 (a) Histogram of $\delta^{13} \mathrm{C}$ values of transition-zone diamonds from Jagersfontein and Monastery (South Africa), the Juína area in Brazil (containing either majorite or Ca-rich inclusions), and Kankan (Guinea). The mantle range (gray band) is defined by the study of fibrous diamonds, mid-ocean ridge basalts, carbonatites, and kimberlites. ${ }^{20,21,81,99-107}$ (b) Histogram of $\delta^{15} \mathrm{~N}$ values of transition zone diamonds from Jagersfontein, Monastery, Brazil, and Kankan. ${ }^{99,101,106,107}$ (c) Schematic history of diamond formation in the transition zone, illustrating the deep recycling of surficial carbon and nitrogen in the mantle. At each locality, transition zone diamonds did not necessarily form during single subduction events. 


\subsubsection{Earth's Deep Water and the Carbon Cycle}

Water coexists with carbon as $\mathrm{CH}_{4}$ or $\mathrm{CO}_{2}$ in mantle $\mathrm{C}-\mathrm{H}-\mathrm{O}$ fluids. Studies of the diamond-bearing carbon cycle also afford a chance to follow water - one of the defining components of Earth's mantle. The mantle transition zone, from 410 to $660 \mathrm{~km}$ depth, was identified 30 years ago as a potentially major sink for water in Earth, ${ }^{110}$ where $\mathrm{H}_{2} \mathrm{O}$ could incorporate into nominally anhydrous minerals as hydroxyl species. Seismic tomography images of some subducted oceanic slabs ponding within the transition zone ${ }^{111}$ brought into focus the potential for this geochemical reservoir to store volatiles recycled along with the oceanic slabs. Despite experimental verification of the high water storage capacity of high-pressure polymorphs of olivine - wadsleyite and ringwoodite (e.g. Kohlstedt et al. ${ }^{112}$ ) - considerable debate ensued regarding the degree of hydration of the mantle transition zone. Its state of hydration is poorly constrained at regional and global scales because of the compensating effects of temperature, bulk composition, and mineralogy in modeling geophysical observations. Diamonds have a unique role to play in illuminating this problem.

Since the discovery of super-deep diamonds, ${ }^{18}$ their immense value in providing samples of the upper mantle, transition zone, and lower mantle has become clear. ${ }^{24,25,98,113-115}$ Several studies discovered olivine inclusions suggested to have previously been wadsleyite or ringwoodite based on frequent spinel exsolutions ${ }^{116}$ or their coexistence with other phases thought to be from the transition zone. ${ }^{18,117,118}$

During the DMGC consortium initiative on super-deep diamonds, a diamond from the Rio Aripuanã in the Juína district of Mato Grosso, Brazil, was found to contain the first terrestrial occurrence of un-retrogressed ringwoodite (Figure 5.6). ${ }^{23}$ This $\sim 30-\mu \mathrm{m}$ inclusion was estimated to contain $\sim 1.4$ wt. $\% \mathrm{H}_{2} \mathrm{O}$. Subsequent recalibration of IR absorbance for hydrous ringwoodite by absolute methods (proton-proton scattering) across the $\mathrm{Mg}_{2} \mathrm{SiO}_{4}-$ $\mathrm{Fe}_{2} \mathrm{SiO}_{4}$ solid solution ${ }^{119}$ refined this estimate to $1.43 \pm 0.27$ wt. $\% \mathrm{H}_{2} \mathrm{O}$. The observed water content in the ringwoodite inclusion is close to the maximum storage capacity $(\sim 2$ wt. $\% \mathrm{H}_{2} \mathrm{O}$ ) observed in experiments at conditions representative of cold-slab geotherms. ${ }^{120}$ This constraint is strong evidence that the host environment for the ringwoodite was a subducted slab carrying significant $\mathrm{H}_{2} \mathrm{O}$ into the transition zone. With such a restricted data set, it remains to be determined how representative the Juína ringwoodite found by Pearson et al. $^{23}$ is for the mantle transition zone at regional scales; however, Nestola and Smyth ${ }^{121}$ estimated that when this water content is applied to the whole mantle transition zone $(\sim 7 \%$ of Earth's mass), the total water content would be $\sim 2.5$ times the volume of water in Earth's oceans. Even if the single natural specimen represents a local phenomenon of water enrichment, seismological evidence of dehydration melting above and below the transition zone $^{122-124}$ and the report of the super-hydrous "Phase Egg" in a super-deep diamond by Wirth et al., ${ }^{125}$ along with other recently described phenomena such as the presence of brucite within ferropericlase $\mathrm{e}^{126}$ and the documentation of ice VII within diamonds originating in the transition zone and lower mantle by Tschauner et al., ${ }^{127}$ provide stunning evidence of linked water and carbon cycles in Earth's mantle extending down into the transition zone and possibly as deep as the top of the lower mantle. 

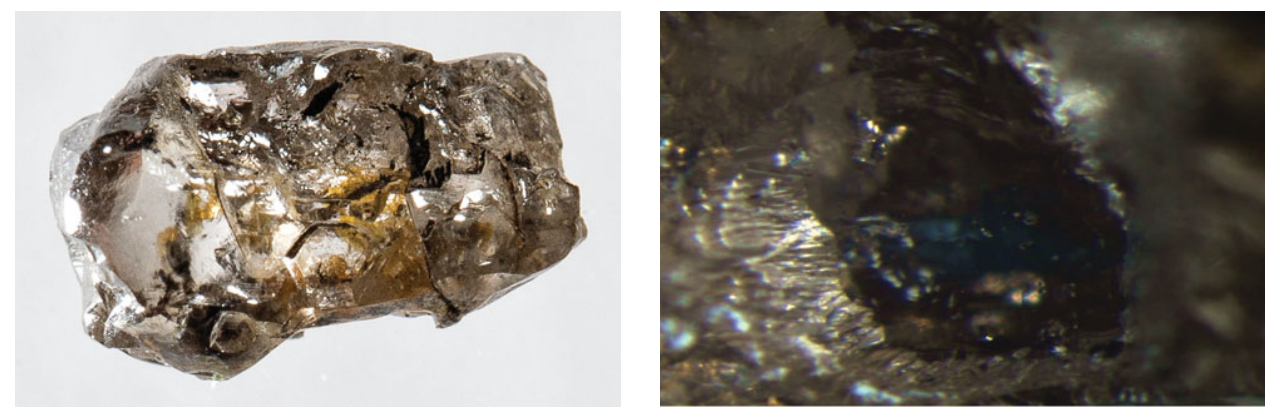

Figure 5.6 Photograph of Juína diamond JuC-29 and a magnified view of the ringwoodite inclusion (right panel, center of image) showing the characteristic indigo-blue color of ringwoodite.

The presence of water in ringwoodite, likely hosted in a cool, subducted oceanic slab along with the recycled signature of carbon and nitrogen evident in transition zone diamonds (see Section 5.4.2) indicate that the transition zone as sampled by diamonds is a reservoir that is potentially dominated by subducted slabs and their recycled volatiles. This region of Earth's mantle is therefore a key zone for the storage and ultimate return of recycled volatiles, including carbon, in Earth.

\subsection{Mineral Inclusions and Diamond Types}

\subsubsection{Experiments to Study Diamond Formation and Inclusion Entrapment}

Experiments on diamond formation and growth have two main goals: gaining a better understanding of diamond-forming reactions and simulating the mechanisms for inclusion entrapment. Both goals address an essential step in the deep carbon cycle where carbon is liberated from fluids or melts and reduced to form diamond. Synthetic diamond growth was one of the driving forces of high-pressure technology, ${ }^{128}$ but for many years the focus remained on their industrial production, which employs metallic liquid solvents, and not on identifying the growth media of natural diamonds. Arima et al. ${ }^{129}$ first synthesized diamond from a kimberlite composition, but since then a very wide range of plausible mantle fluid and melt compositions have yielded synthetic diamonds, including pure carbonates, ${ }^{130} \mathrm{C}-\mathrm{H}-\mathrm{O}$ fluids, ${ }^{131}$ carbonate-silicate mixtures with water and/or chloride, ${ }^{132,133}$ and metal sulfides. ${ }^{134}$ Palyanov et al. ${ }^{130}$ achieved diamond nucleation using $\mathrm{Na}_{2} \mathrm{CO}_{3}+\mathrm{C}-\mathrm{H}-\mathrm{O}$ fluid mixtures at $1150^{\circ} \mathrm{C}$ and $5.7 \mathrm{GPa}$, overcoming the nucleation barrier exhibited by direct graphite transformation that exists throughout cratonic lithosphere conditions. Further studies have shown nucleation and growth to be greatly promoted by the presence of $\mathrm{H}_{2} \mathrm{O} .{ }^{135-137}$ There is further evidence that $\mathrm{NaCl}$ may act to reduce the growth rate. ${ }^{132,136}$ Experiments to synthesize diamonds from reduced $\mathrm{C}-\mathrm{H}-\mathrm{O}$ fluids have been less successful. Diamond formation was found to be inhibited in the 
presence of $\mathrm{CH}_{4}-\mathrm{H}_{2}$ fluids, for example, ${ }^{131,138}$ although recent measurements of $\mathrm{CH}_{4}$ imply that diamonds do indeed grow naturally with such reduced fluids. ${ }^{40}$

Experiments examining natural diamond growth media are generally performed with excess graphite, and in the absence of an obvious reducing agent the main formation mechanism is dissolution and precipitation along a decreasing temperature gradient. ${ }^{139}$ Luth and Stachel ${ }^{47}$ have argued that a thermal gradient growth process may form diamonds in the mantle because the dissolved carbon content of a $\mathrm{C}-\mathrm{H}-\mathrm{O}$ fluid in equilibrium with diamond decreases with temperature and also with pressure. Diamond growth from cooling or decompressing fluids overcomes the difficulty of dissolved carbon species being reduced or oxidized by external agents such as ferric or ferrous iron, which are not present in wall rocks at the concentrations required to account for natural macroscopic diamond growth. Calculations show that, in a $\mathrm{C}-\mathrm{H}-\mathrm{O}$ fluid, the greatest change in diamond solubility with temperature occurs at the so-called $\mathrm{H}_{2} \mathrm{O}$ maximum, where the carbon content of the fluid is actually at a minimum. ${ }^{47}$ This may explain why diamond growth is promoted in experiments with high $\mathrm{H}_{2} \mathrm{O}$ concentrations. ${ }^{136,137}$ One problem with this occurring in the mantle is that the $\mathrm{H}_{2} \mathrm{O}$ contents of mineral inclusions such as olivine trapped in diamonds should be near $\mathrm{H}_{2} \mathrm{O}$ saturation, which seems not to be the case for the lithospheric diamonds measured to date. ${ }^{140}$ Reduced $\mathrm{CH}_{4}$-rich fluids, on the other hand, experience relatively small changes in carbon solubility with temperature, but much larger changes with pressure. ${ }^{47}$ This, coupled with problems of $\mathrm{H}_{2}$ loss from capsules at reducing conditions, may at least partly explain the difficulties in diamond synthesis from $\mathrm{CH}_{4}$-rich fluids.

Inclusions trapped in diamonds are among the few diagnostic tools that can constrain diamond growth media, and recent experiments have attempted to explore this link by capturing inclusions in synthetically grown diamonds. Experiments using water-rich mixtures containing carbonates and silicates have successfully produced a broad range of mineral, melt, and fluid inclusions at 6-7 GPa and $1300-1400^{\circ} \mathrm{C}$ (Figure 5.7). ${ }^{136,137}$ Starting compositions were based on fluid inclusion analyses of fibrous diamonds, ${ }^{61}$ and polycrystalline and fibrous growth textures were reproduced, which tended toward monocrystalline growth at higher temperatures. Bureau et al. ${ }^{137}$ used observations of coexisting melt and fluid inclusions to infer the temperature where the two phases become miscible in the system examined. Bataleva et al. ${ }^{141}$ also captured inclusions in monocrystalline diamonds grown from $\mathrm{SiO}_{2}-(\mathrm{Mg}, \mathrm{Ca}) \mathrm{CO}_{3}-(\mathrm{Fe}, \mathrm{Ni}) \mathrm{S}$ mixtures at $6.3 \mathrm{GPa}$ and $1650-1750^{\circ} \mathrm{C}$. The inclusions, which encompassed quenched carbonate-silicate melts, sulfide melts, and $\mathrm{CO}_{2}$ fluid, reflected, in part, the growth medium that is generally assumed for natural diamond inclusions, but Bureau et al. ${ }^{136}$ demonstrated that carbonate minerals are readily trapped in diamonds that are actually growing from $\mathrm{H}_{2} \mathrm{O}$-dominated liquids.

The alternative to diamond growth from cooling or decompressing $\mathrm{C}-\mathrm{H}-\mathrm{O}$-rich liquids is precipitation due to redox reactions with iron or potentially sulfide species in surrounding minerals or melts. This would seem to be problematic, as mentioned above, because iron species and sulfides lack the redox capacity to reduce or oxidize macroscopic 

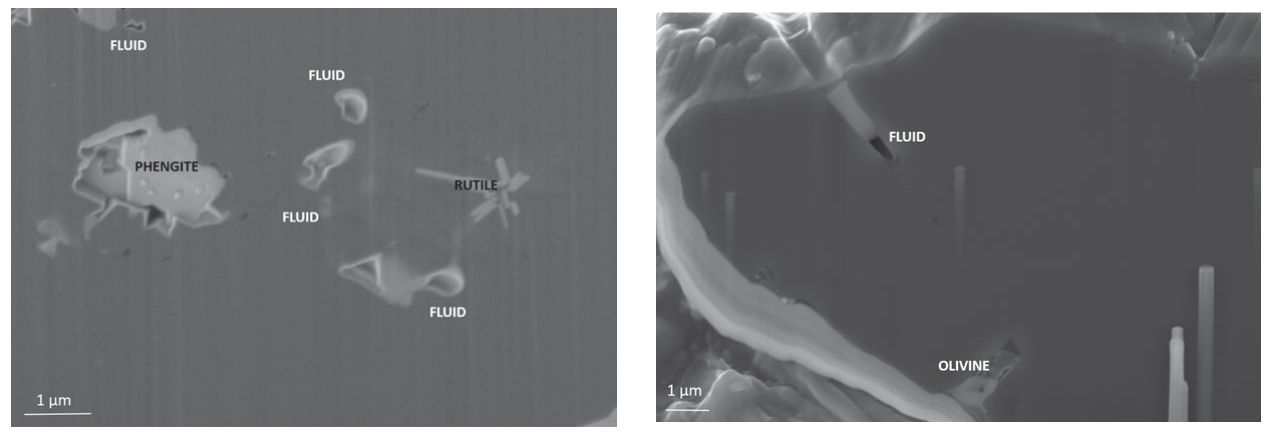

Figure 5.7 Scanning electron microscope images of monocrystalline diamond slices containing trapped inclusions, prepared by focused ion beam thinning from diamonds synthesized at $7 \mathrm{GPa}$ and $1300^{\circ} \mathrm{C}$ for 30 hours. The fluid is lost from the inclusions once they become exposed, leaving only cavities.

diamonds from fluids. ${ }^{47}$ With the recognition that the mantle may become metal saturated at depths $>200 \mathrm{~km}$, however, a number of experiments have studied a so-called redox freezing scenario ${ }^{142}$ where carbonate melts may migrate out of subducting slabs and rise into the overlying metal-saturated sublithospheric mantle. ${ }^{57,143}$ An intriguing result is that the oxidation of iron and reduction of carbonate in these experiments form magnesiowüstite with a wide range of Fe contents, ${ }^{143}$ which is consistent with its occurrence in sublithospheric diamonds.

\subsubsection{Nanoscale Evidence for Polycrystalline Diamond Formation}

Carbon that does not occur as monocrystalline diamond but rather as a polycrystalline diamond aggregate (PDAs; "framesites," ${ }^{144}$ boart, ${ }^{145}$ or diamondite ${ }^{146}$ ) represent a littlestudied variety of carbon in the mantle that has the potential to reveal how carbon percolates at shallower levels of diamond stability. The PDAs can make up 20\% of the diamond production in some Group I kimberlites (K. de Corte, pers. comm. 2012), but are not reported from Group II kimberlites, nor other diamondiferous volcanic rocks. Their polycrystalline nature indicates rapid precipitation from carbon-oversaturated fluids. ${ }^{145}$ Compared to monocrystalline diamonds, individual PDAs often contain a more varied and chemically heterogeneous suite of inclusions and minerals intimately intergrown with the diamond crystals. However, these inclusions are sometimes not shielded from metasomatism and alteration, which can accompany deformation and recrystallization of the diamonds as seen in electron-backscatter diffraction images. ${ }^{147}$ The suite of minerals found in PDAs, while derived from Earth's mantle, is unlike inclusions in diamond; websteritic and pyroxenitic parageneses dominate and olivine is absent. Individual grains commonly are chemically and structurally heterogeneous, ${ }^{148,149}$ suggesting that many grew by reaction between mantle minerals and metasomatic fluids and/or melts. Trace element patterns of the silicates can show signatures of carbonatite metasomatism, supporting their 
formation from oxidized fluids. However, some samples contain very reduced inclusions, such as iron carbide. ${ }^{150}$ Thus, a single formation process is unlikely. Like the associated websteritic and pyroxenitic silicates, the non-silicate phases such as magnetite may represent reaction products associated with diamond formation. Jacob et al. ${ }^{148}$ documented epitactic relations between grains of iron sulfide, which oxidized to magnetite and served as nucleation templates for the host diamond crystals, underlining the role of redox reactions in diamond formation. Textural evidence for a high-pressure $\mathrm{Fe}_{3} \mathrm{O}_{4}$ precursor phase constrains the depth of formation of the PDAs to the base of the lithosphere. Hence, this variety of diamond, due to its rapid formation, provides insights into the extreme "corners" of the diamond formation process in Earth's SCLM. Such evidence is often eradicated in larger monocrystalline diamonds, which grow slowly and record time-integrated evidence within the deep carbon cycle. Several questions require answers in order for us to understand the role of PDAs and their context in the deep carbon cycle.

Applying robust constraints on absolute ages proves difficult for PDAs, and the sparse data available suggest episodic formation. Jacob et al. ${ }^{149}$ observed trace element zonation in PDA-hosted garnets from Venetia (South Africa); modeling using known diffusion coefficients showed that the preservation of the zoning requires that these samples precipitated shortly before kimberlite eruption. The garnets show unradiogenic $\varepsilon_{\mathrm{Nd}}(-16$ to -22$)$; this implies that they contain older lithospheric material remobilized with the carbonbearing fluid to form PDAs. However, the nitrogen aggregation states of PDAs (probably from southern Africa) showed that these samples are not exclusively young, but formed in several distinct events over a long time span, possibly more than millions of years. ${ }^{151}$

Carbon isotope values $\left(\delta^{13} \mathrm{C}\right)$ in PDAs span a range from ca. $-1 \%$ to ca. $-30 \%$ $(n=115)$ with peaks at $-5 \%$ and at $-19 \%$. ${ }^{152,153}$ The first peak is the typical mantle, ${ }^{8}$ but the second peak at $-19 \%$ is typical only for PDAs ${ }^{8}$ and, to date, remains unexplained. Nitrogen concentrations and $\delta^{15} \mathrm{~N}$ in PDAs cover large ranges: $4-3635$ at. ppm and $-6.1 \%$ to $+22.6 \%$, ${ }^{152,154,155}$ but both are independent of $\delta^{13} \mathrm{C}$ values, arguing against broad-scale fractionation processes. ${ }^{5,155,156}$ Some authors have argued for Rayleigh fractionation of a mantle-derived fluid, ${ }^{5,156}$ while others inferred a subducted fluid origin. ${ }^{151,152}$ A role for a subducted component is supported by the high nitrogen concentrations in some of the diamonds, combined with heavy nitrogen isotopic compositions - typical for material from Earth's surface. ${ }^{151,152}$

Collectively, these data imply that PDAs are the product of small-scale reactions with fluids related to both ambient mantle carbon, remobilized SCLM material, and subducted crustal carbon. The formation of PDAs also requires interaction of melts and rocks within the subcratonic lithosphere, and these events are episodic. These fluid-driven, rapid reactions serve to "freeze" carbon as diamond in the subcratonic lithosphere, and they may preserve some of the best evidence for small-scale chemical heterogeneity at the site of formation. Obtaining accurate information on the age and depth of polycrystalline diamond formation is the next step to addressing their role in the deep carbon cycle, since they may represent the shallowest form of diamond-forming fluid. 


\subsubsection{Proterozoic Lherzolitic Diamond Formation: A Deep and Early Precursor to Kimberlite Magmatism}

Lithospheric diamonds are ancient and form during episodes of fluid infiltration into the lithospheric mantle keel in response to large-scale geotectonic processes. Studies of lithospheric diamonds provide the main way to look back at carbon cycling over the past 3.5 billion years. The continental lithosphere has been recognized as an important carbon reservoir, which, after initial melt extraction imposing highly refractory and reducing conditions, was gradually re-enriched and re-oxidized through infiltration of volatilebearing fluids and melts from episodically impinging plumes and subducting slabs. ${ }^{157}$ Kimberlite eruptions, which increased in frequency through time (Figure 5.8), sporadically connect this deep lithospheric carbon cycle to surface reservoirs, but require conditions that are favorable to their formation and extraction from a carbonated mantle source. ${ }^{158-160}$ The cryptic part of the lithospheric carbon cycle involving diamonds can be illuminated through a combination of age dating and chemical characterization of the inclusions in the diamonds, which reveal the nature of their source rocks and their formation conditions. ${ }^{58}$ Diamond formation through time reveals a trend, from harzburgitic sources prior to $3 \mathrm{Ga}$, to the first appearance of eclogitic diamonds ca. $3 \mathrm{Ga}^{17}$ and of lherzolitic diamonds and renewed diamond growth in the Proterozoic recording ages from ca. 2.1 to $0.7 \mathrm{Ga}$ (Figure 5.8). Thus, Proterozoic lherzolitic diamond formation is a widespread phenomenon, corresponding to $\sim 12 \%$ of inclusion-bearing peridotitic lithospheric diamonds. ${ }^{10}$ Refertilization (lherzolitization) of the initially depleted lithosphere and minor associated diamond growth likely occurred in the presence of small-volume melts, producing garnet inclusions with characteristic, generally mildly sinusoidal REE patterns. ${ }^{58}$

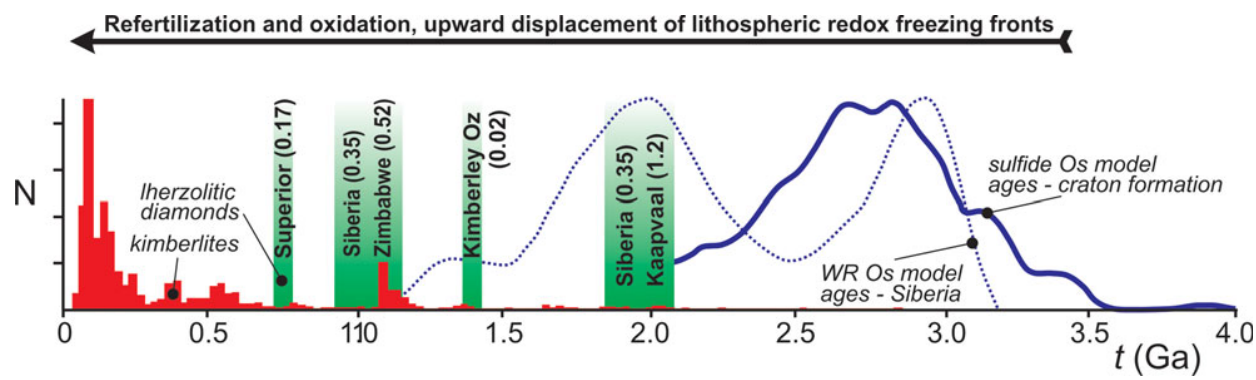

Figure 5.8 Lherzolitic diamond formation through time: ca. 2.1 to $1.8 \mathrm{Ga}$, diamonds from Premier (Kaapvaal craton) and 23rd Party Congress/Udachnaya (Siberian craton); $1.4 \mathrm{Ga}$, diamonds from Ellendale (Western Australia); ${ }^{161} 1.1$ to $1.0 \mathrm{Ga}$, diamonds from 23rd Party Congress/Mir (Siberian craton) ${ }^{162}$ and Venetia (Zimbabwe craton); ${ }^{163}$ and $0.72 \mathrm{Ga}$, diamonds from Attawapiskat (Superior craton). ${ }^{164}$ Numbers in parentheses give host kimberlite eruption ages (in giga-years) to illustrate the delay between lherzolitization and kimberlite magmatism. Shown for comparison is the age distribution of kimberlites from Tappe et al., ${ }^{160}$ Os model ages of mantle sulfides from Griffin et al., ${ }^{165}$ which predominantly reflect the time of Archaean craton formation and the creation of strongly refractory and reducing mantle lithosphere, and for xenoliths from the Siberian craton, which show a major Paleoproterozoic lithospheric mantle formation event. ${ }^{166}$ 
The successful eruption of kimberlites has been suggested to require, inter alia, metasomatic oxidative "preconditioning" of deep lithospheric pathways in the presence of diamond ${ }^{167}$ and of shallower lithospheric levels through the precipitation of hydrous and Ti minerals from kimberlite precursors. ${ }^{168}$ Although harzburgitic source rocks are too $\mathrm{Fe}^{3+}$ depleted to permit substantial diamond formation by wall rock-buffered redox reactions, ${ }^{47}$ lherzolitization accompanied by (ferrous) iron introduction may have restored sufficient redox buffering capacity to precipitate some diamonds by reduction of carbonate from small-volume melts through simultaneous oxidation of $\mathrm{Fe}^{2+}$ to $\mathrm{Fe}^{3+}$ of the host rock. Indeed, very depleted initial source compositions inferred from average $\mathrm{FeO}$ contents in refractory garnet peridotites from various cratons (5.3-6.8 wt.\%) give way to higher $\mathrm{FeO}$ contents (6.3-7.4 wt.\%) when metasomatized lherzolites are included (data in Aulbach ${ }^{169}$ ). Some metasomatism was likely accompanied by oxidation and an increase in $\mathrm{Fe}^{3+} / \sum \mathrm{Fe}$, as indicated by the higher $\mathrm{fO}_{2}$ determined for enriched compared to depleted mantle xenoliths. ${ }^{167,170,171}$ Pervasive interaction of the deep mantle column with (proto)kimberlite melts is confirmed by isotopic and trace element studies of mantle xenoliths. ${ }^{172,173}$ Moreover, (hydrous) carbonated melts diluted with silicate components, similar to kimberlites, can be stable at lower $\mathrm{fO}_{2}$ than pure carbonatite. ${ }^{46}$ Notably, lherzolitic diamond formation is temporally and genetically dissociated from the later-emplaced kimberlite hosts of these diamonds (Figure 5.8). Within this framework, Proterozoic lherzolitic diamond formation has recently been suggested to represent the deep and early component of the refertilization and reoxidation of the lithosphere required for successful kimberlite eruption. ${ }^{164}$ Given the recent advances in experimental and thermodynamic groundwork, the task is now to quantitatively delineate carbon speciation in the cratonic lithosphere through space and time, including the potential role of lherzolitic diamond formation as part of the upward displacement of redox freezing fronts that culminate in kimberlite eruption.

\subsubsection{Diamond Growth by Redox Freezing from Carbonated Melts in the Deep Mantle}

The bulk composition and trace element distributions in mineral inclusions in super-deep diamonds provide information about the conversion of carbonate to diamond in the deep upper mantle, transition zone, and lower mantle. Of the wide range of inclusions found in super-deep diamonds, those with bulk compositions consistent with Ca-rich majorite garnet and Ca-rich silicate perovskite have provided the most compelling evidence for the role of carbonated, subducted oceanic crustal materials in their origin (e.g. Refs. 18, 20, $21,49,56,98,100,102,105,118,174-176)$.

Inclusions interpreted as former majorite garnet or Ca-perovskite often exhibit composite mineralogy that is interpreted to have formed by unmixing from primary precursor minerals exhibiting solid solution (e.g. Refs. 12, 20, 21, 56, 102, 175, 177). Inclusions formed as majorite solid solutions typically unmix upon uplift in the mantle to a mixture of pyrope-rich garnet and clinopyroxene (e.g. Refs. 12, 21, 177), and on the basis of majorite 

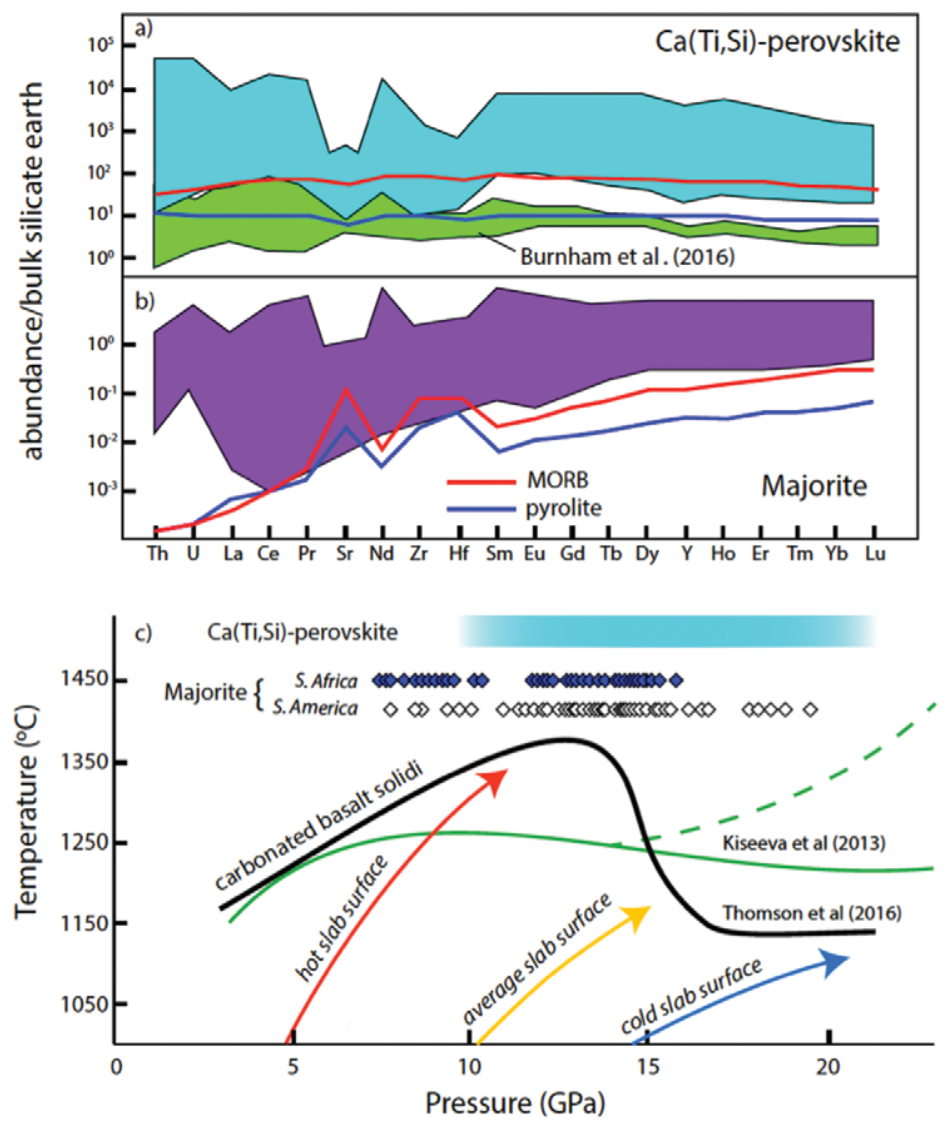

Figure 5.9 Bulk silicate earth normalized trace element composition of (a) "calcium silicate perovskite" and (b) majoritic garnet inclusions compared with models for these phases in subsolidus peridotite (blue) and MORB (red) at transition-zone conditions, as described in Thomson et al. ${ }^{57}$ Inclusion compositions are from Davies et al., ${ }^{180}$ Stachel et al., ${ }^{98,178}$ Kaminsky et al., ${ }^{100}$ Tappert et al., ${ }^{105}$ Bulanova et al., ${ }^{21}$ Hutchison, ${ }^{99,181}$ Moore et al., ${ }^{182}$ and Burnham et al. ${ }^{103}$ (c) Pressure-temperature plot showing the solidi of model carbonated MORB with $2.5 \mathrm{wt} . \% \mathrm{CO}_{2}{ }^{176}$ and $~ 4.5 \% \mathrm{CO}_{2}{ }^{179}$ relative to model geotherms for slab surface temperature at modern subduction zones (Syracuse et al. ${ }^{183}$ ). The solidi create a depth interval over which most slab surface temperatures intersect the melting curves, producing a region of carbonated melt generation.

Also shown are calculated pressures of majoritic garnet inclusions in diamonds from South America and South Africa, ${ }^{21,57,100,102,105,177,178,181,184,185}$ calculated from the barometer of Beyer et al. ${ }^{186}$

geobarometry, these inclusions originated at pressures of $\sim 7-20$ GPa (Figure 5.9), with most inclusions forming in the range of $\sim 10-17 \mathrm{GPa}$; that is, in the deep upper mantle and shallow transition zone. Super-deep majorite inclusions are almost exclusively high $\mathrm{Ca}$ and low $\mathrm{Cr}$, indicating petrogenesis involving mafic protoliths (e.g. Refs. 12, 21, 178, 179).

Inclusions interpreted to have originated as Ca-rich perovskite come in two varieties: $\mathrm{Ti}$ rich and $\mathrm{Ti}$ poor. Ti-rich inclusions typically unmix to nearly phase-pure 
$\mathrm{CaTiO}_{3}$-perovskite plus walstromite, larnite, titanite, or wollastonite, whereas $\mathrm{CaSiO}_{3}$ varieties are typically walstromite. An important feature of nearly all Ca-perovskite inclusions is their very low $\mathrm{MgO}$ content, typically $<0.5 \mathrm{wt} . \%$, which effectively precludes equilibration in the lower mantle with bridgmanite at mantle temperatures. ${ }^{187}$ This observation, together with phase relations in the $\mathrm{CaSiO}_{3}-\mathrm{CaTiO}_{3}$ system, ${ }^{188}$ constrains the original Ti-rich perovskites to have formed between $\sim 10$ and $25 \mathrm{GPa}$, similar to the majorite inclusions. The exception are some rare occurrences of Ti-poor $\mathrm{CaSiO}_{3}$ inclusions that have moderate $\mathrm{MgO}$ contents, and these may have formed in a lower mantle, peridotitic protolith. ${ }^{103}$

A feature common to most Ca-perovskite and majorite inclusions is extreme enrichment in trace elements. ${ }^{20,21,56,174,178,189}$ Figure 5.9 shows normalized trace element abundances in inclusions compared to the modeled abundances for these phases in either mantle peridotite or subducted basalt at transition-zone pressures. These inclusions are not fragments of ambient solid mantle or subducted basalt, and in many cases the most incompatible elements are four to five orders of magnitude more abundant than expected for minerals in these lithologies. Wang et al. ${ }^{174}$ suggested a role for carbonated melt in the origin of Ca-perovskite inclusions, and the distinct trace element patterns in Ca-perovskite and majorite inclusions from Juína, Brazil, indicate that the inclusions crystallized from carbonated melt derived from subducted oceanic crust. $^{20,21,56,176,189}$

The involvement of recycled crustal components in the origin of super-deep diamonds is supported by observations that the diamond hosts show a wide range of carbon isotope compositions extending to very light values (e.g. $\sim 0 \%$ to $-25 \%)^{20,21}$ and that majorite garnet and other silicate inclusions have isotopically heavy oxygen isotope compositions. ${ }^{104,109}$ The high and variable ferric iron content of majorite inclusions is also consistent with an oxidized carbonate component in their origin. ${ }^{190}$

The solidus of carbonated basalt is notably depressed at deep upper-mantle and transition zone pressures (e.g. Refs. 57, 179), and in model MORB composition with $2.5 \% \mathrm{CO}_{2}$, a deep a solidus ledge occurs at pressures of 10-15 GPa (Figure 5.9). ${ }^{57}$ Model geotherms for hot and average surface slab temperatures ${ }^{183}$ intersect the carbonated basalt solidi, and only the coldest slab surface geotherms can escape melting. Carbonated basalt will melt in the deep upper mantle and transition zone and produce alkali-rich silico-carbonate melts.

Mantle peridotite is reducing and expected to be saturated in metal at transition zone depths. ${ }^{142}$ Upon infiltration into the mantle, oxidized carbonated melts will reduce to diamond plus oxygen in a process called "redox freezing." ${ }^{142}$ Experiments mimicking this process show that, upon reaction with peridotite at transition zone pressures, such melts can crystallize calcic majorite and Ca-perovskite with compositions matching those found as inclusions. ${ }^{57}$ This melt metasomatism can also produce both $\mathrm{Fe}$ - and $\mathrm{Mg}$-rich periclase, ${ }^{57}$ which are common minerals in super-deep assemblages (e.g. Refs. 12, 191). Some large, gem-quality super-deep diamonds show evidence of growing directly from carbon-saturated metallic melts, ${ }^{49}$ testifying to a wide range of redox conditions in deeply subducted material. 
Future studies will concentrate on determining the role of low-degree, volatile-rich melts in a wider array of inclusions in super-deep diamonds, elucidate the role of water, model the reactive transport processes by which this melt metasomatism occurs, and determine its role in modifying mantle elemental and isotopic compositions.

\subsubsection{Evidence for Carbon-Reducing Regions of the Convecting Mantle}

The existence, extent, and scale of oxidized versus reduced regions of the convecting mantle are critically important to understanding how carbon moves around at depth. Large and relatively pure diamonds have recently been shown to contain key physical evidence of metallic iron from the deep sublithospheric mantle, ${ }^{49,192}$ suggesting that metallic iron may be one of the principal reservoirs of mantle carbon in this region. As a family, diamonds like the historic 3106 carat Cullinan diamond tend to be large, inclusion poor, relatively pure (usually Type IIa), and in their rough state they are irregularly shaped and significantly resorbed. ${ }^{49,193,194}$ These characteristics are combined into the acronym "CLIPPIR" (Cullinan-like, Large, Inclusion Poor, Pure, Irregular, and Resorbed) to label this genetically distinct diamond variety.

Out of 81 inclusion-bearing CLIPPIR diamonds, the most common inclusion encountered is a composite, metallic iron-nickel-carbon-sulfur mixture (Figure 5.10). In fact, 60 of the 81 samples contain only this inclusion, which attests to its predominance in the CLIPPIR variety. ${ }^{192}$ The metallic inclusions are a made up of cohenite $\left((\mathrm{Fe}, \mathrm{Ni})_{3} \mathrm{C}\right)$, interstitial $\mathrm{Fe}-\mathrm{Ni}$ alloy, segregations of Fe-sulfide, and minor occasional $\mathrm{Fe}-\mathrm{Cr}$-oxide, Fe-oxide, and Fe-phosphate. ${ }^{192} \mathrm{~A}$ thin fluid layer of $\mathrm{CH}_{4}$ and lesser $\mathrm{H}_{2}$ is trapped at the interface between the solid inclusion and surrounding diamond. The mixture is interpreted to have been trapped as a molten metallic liquid.

Other inclusions found in CLIPPIR diamonds represent high-pressure silicates, which provide a constraint for the depth of diamond formation. The second most abundant

(a)

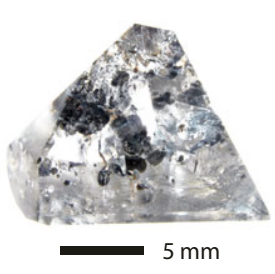

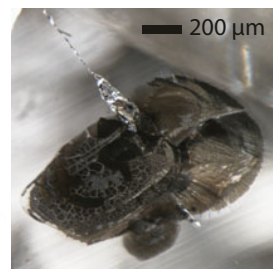

(b)

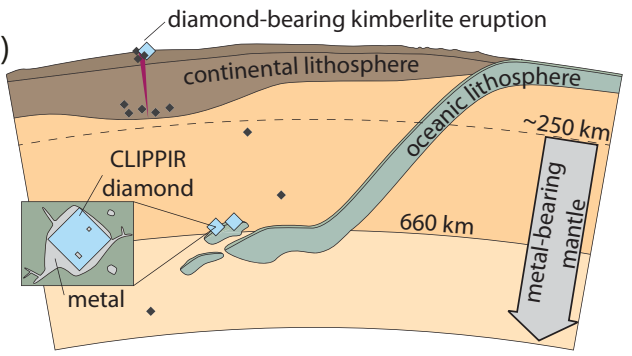

Figure 5.10 (a) Metallic inclusions in a 9.56 carat CLIPPIR diamond with an enlargement of one of the inclusions. These metallic inclusions sometimes have a needle-like tail and typically have large, graphitic decompression cracks around them. (b) Depth constraints place the origin of these diamonds within $360-750-\mathrm{km}$ depths in the mantle, where they are associated with subducted lithologies. The metallic inclusions are evidence for reduced, metal-bearing regions of the deep mantle below a depth of approximately $250 \mathrm{~km}$. 
inclusion, after the metallic $\mathrm{Fe}-\mathrm{Ni}-\mathrm{C}-\mathrm{S}$, is a mix of calcium silicates interpreted as retrogressed $\mathrm{CaSiO}_{3}$-perovskite $(\mathrm{CaPv})$, which is a high-pressure mineral stable at depths beyond about $360 \mathrm{~km} \cdot{ }^{25,31,195}$ An additional inclusion phase found was low-Cr majoritic garnet, which provides a maximum depth bracket, since it is not stable deeper than about $750 \mathrm{~km} .{ }^{196}$ Silicate inclusion phases therefore bracket the depth to $360-750 \mathrm{~km}$, overlapping the mantle transition zone.

The Fe-Ni-C-S inclusions in CLIPPIR diamonds are physical samples of an Fe-rich metallic liquid from the deep mantle, which help to confirm the fundamental process of $\mathrm{Fe}^{2+}$ disproportionation at depth. ${ }^{49}$ Disproportionation is driven by the progressive increase in the capacity for silicate minerals to host $\mathrm{Fe}^{3+}$ preferentially over $\mathrm{Fe}^{2+}$ with increasing pressures, promoting the following reaction: $3 \mathrm{Fe}^{2+} \rightarrow 2 \mathrm{Fe}^{3+}+\mathrm{Fe}^{0}$. The "oxidized" $\mathrm{Fe}^{3+}$ is partitioned into the silicates, but the "reduced" $\mathrm{Fe}^{0}$ separates into its own metallic phase, which is thought to generate up to about $1 \mathrm{wt} . \%$ metal in the lower mantle. ${ }^{142,197-199}$ This metal budget should regulate $f \mathrm{O}_{2}$, keeping it near the iron-wüstite buffer below $\sim 250 \mathrm{~km}$ and establishing a carbon-reducing environment in much of the deep mantle. ${ }^{142}$ The solubility of carbon in metallic Fe liquid is very high, up to $\sim 6 \mathrm{wt} . \%$, and it is $\sim 2 \%$ in solid Fe metal at lower temperatures. Thus, in regions of the transition zone and lower mantle where metallic Fe exists, the mantle's entire budget of carbon might be dissolved in Fe metal and diamond would not be a stable phase.

In order to confirm the experiments and theory that the bulk of Earth's mantle below $\sim 250 \mathrm{~km}$ is likely saturated with metallic iron, ${ }^{198-200}$ obtaining direct samples is important because the behavior of carbon in the mantle is so strongly affected by oxygen fugacity. In a metal-saturated mantle, carbon is expected to be efficiently reduced and dissolved into the metal phase, or potentially precipitated as carbide or diamond, ${ }^{142}$ and this has largescale implications for the behavior of carbon in the mantle over geologic time. In CLIPPIR diamonds, variably light carbon isotopic signatures as well as the composition of majoritic garnet inclusions suggest the involvement of subducted materials. ${ }^{49}$ This additional observation implies that deeply recycled carbon can enter into carbon-reducing regions of the mantle and become dissolved into metallic phases. Thus, dispersed Fe-rich metal in the deeper, convecting mantle may contain both primordial and recycled carbon, whose proportions may have changed with time. Further research into the influence of metallic iron on carbon in the mantle will explore the evolution of storage and cycling, from core formation to the onset of modern-style plate tectonics.

\subsection{Limits to Knowledge and Questions for the Future}

Limits to knowledge in diamond research have been the typical occurrence of each diamond as a single isolated xenocryst, its pure crystal structure, the rarity of inclusions, and the availability of samples (see Section 5.1). The DMGC consortium was conceived early in the existence of the DCO to help overcome these and other obstacles to reaching the following major goals: (1) a research focus on the most widely occurring carbon mineral on Earth; (2) the use of diamond's special ability to preserve mineral inclusions, 
fluid species, and pathways from great depths and ages to provide a view of the otherwise inaccessible deep carbon cycle; and (3) application of cross-disciplinary research tools and sharing of samples necessary to go beyond a single investigator or research group.

Future directions in diamond research in relation to the bigger picture of carbon in the deep Earth are best summed up with a list of questions:

- What is the source of carbon and other volatiles returned by diamond from the deep mantle?

- How can the findings from diamond studies be extrapolated to the bulk mantle?

- What is the mineralogy and composition of the major deep mantle minerals?

- What is the capacity for carbon and water storage in deep mantle minerals?

- How and why do contrasting (carbonatitic versus metallic versus supercritical C-H-O fluids) diamond-forming environments exist?

- What are the most effective mechanisms for diamond formation in these different mantle environments?

- Do the $\mathrm{C}$ and $\mathrm{N}$ isotopic compositions of diamonds vary with geologic time, and if so, do they record major geodynamic changes?

- What is the nature of diamond-forming fluids in the lithosphere, what are the mechanisms for their movement through the lithosphere, and what is their relation to geologic events?

- How are accurate entrapment pressures and temperatures determined for mineral inclusions?

- How do the fluids around mineral inclusions in gem diamonds compare with the hydrous-silicic fluids in fibrous diamonds?

- What are the phase transformations in subducting slabs that allow some carbon, water, and other volatiles to be carried to the transition zone?

Taken in total, the studies made by the DMGC consortium will provide new insights into how carbon behaves and resides in both the lithosphere and the deeper convecting mantle. Moreover, through diamond's remarkable attributes, diamond studies will allow us to go beyond the study of carbon alone, to make fundamental discoveries on the nature of the deep Earth that is inaccessible in any other way, and to understand the spectrum of geological processes that govern how carbon gets into the mantle and the form in which it resides.

\section{Acknowledgments}

The authors thank the following institutions and individuals: our home institutions; SBS and EHH for support from the US National Science Foundation (EAR-104992); FN and PN for support from the European Research Council Starting Grant (\#307322); Wuyi Wang and Tom Moses of the Gemological Institute of America (GIA) for the support of the research projects undertaken by KVS and EMS; and SCK for the support of De Beers Technologies. This is contribution 1168 from the ARC Centre of Excellence for Core to 
Crust Fluid Systems (www.ccfs.mq.edu.au) and 1130 in the Geochemical Evolution and Metallogeny of the Continents Key Centre (www.gemoc.mq.edu.au). Over the years, we have benefitted from discussions and collaborations with other DMGC consortium researchers who are not coauthors of this chapter: Galina Bulanova, Jeffrey Harris, Dan Howell, Shantanu Keshav, Stephen Richardson, Chris Smith, Nikolai Sobolev, and Laura Speich. During the preparation of this chapter, our coauthor and leader within the DCO, Erik H. Hauri, died tragically. We remember him as a champion of diamond research and thank him posthumously for his strong support.

\section{References}

1. Gurney, J. J., Helmstaedt, H. H., Richardson, S. H. \& Shirey, S. B. Diamonds through time. Economic Geology 105, 689-712 (2010).

2. Harris, J. W. Diamond geology. In The properties of natural and synthetic diamond (ed. J. E. Field) 345-394 (Academic Press, 1992).

3. Harris, J. W. The recognition of diamond inclusions. Part I: Syngenetic inclusions. Industrial Diamond Review 28, 402-410 (1968).

4. Harris, J. W. \& Gurney, J. J. Inclusions in diamond. In The properties of diamond (ed. J. E. Field) 555-591 (Academic Press, 1979).

5. Deines, P. The carbon isotopic composition of diamonds: Relationship to diamond shape, color, occurrence and vapor composition. Geochimica et Cosmochimica Acta 44, 943-962 (1980).

6. Pearson, D. G., Canil, D. \& Shirey, S. B. Mantle samples included in volcanic rocks: Xenoliths and diamonds. In Teatise on geochmistry: Vol. 2, the mantle (ed. R. W. Carlson) 171-277 (Elsevier, 2003).

7. Pearson, D. G. \& Shirey, S. B. Isotopic dating of diamonds. In Application of radiogenic isotopes to ore deposit research and exploration. Vol. 12, reviews in economic geology (eds. D. Lambert David \& Joaquin Ruiz) 143-171 (Society of Economic Geologists, 1999).

8. Cartigny, P. Stable isotopes and the origin of diamond. Elements 1, 79-84 (2005).

9. Stachel, T., Brey, G. P. \& Harris, J. W. Inclusions in sublithospheric diamonds: Glimpses of deep earth. Elements 1, 73-87 (2005).

10. Stachel, T. \& Harris, J. W. The origin of cratonic diamonds - Constraints from mineral inclusions: The genesis of gem deposits. Ore Geology Reviews 34, 5-32 (2008).

11. Spetsius, Z. V. \& Taylor, L. A. Diamonds of Yakutia: Photographic evidence for their origin (Tranquility Base Press, 2008).

12. Harte, B. Diamond formation in the deep mantle: The record of mineral inclusions and their distribution in relation to mantle dehydration zones. Mineralogical Magazine 74, 189-215 (2010).

13. Tappert, R. \& Tappert, M. C. Diamonds in nature: A guide to rough diamonds (Springer Verlag, 2011).

14. Shirey, S. B. et al. Diamonds and the geology of mantle carbon. Reviews in Mineralogy and Geochemistry 75, 355-421 (2013).

15. Shirey, S. B. \& Shigley, J. E. Recent advances in understanding the geology of diamonds. Gems and Gemology 49, 188-222 (2013). 
16. Stachel, T. \& Harris, J. Formation of diamond in the Earth's mantle. Journal of Physics: Condensed Matter 21, 364206 (2009).

17. Shirey, S. B. \& Richardson, S. H. Start of the Wilson cycle at 3 Ga shown by diamonds from subcontinental mantle. Science 333, 434-436 (2011).

18. Harte, B., Harris, J. W., Hutchison, M. T., Watt, G. R. \& Wilding, M. C. Lower mantle mineral associations in diamonds from Sao Luiz, Brazil. In Mantle petrology; field observations and high-pressure experimentation: A tribute to Francis R. (Joe) Boyd. Vol. 6, special publication - Geochemical Society (eds. Y. Fei, C. M. Bertka \& B. O. Mysen) 125-153 (Geochemical Society, 1999).

19. Anzolini, C. et al. Depth of formation of $\mathrm{CaSiO}_{3}$-walstromite included in super-deep diamonds. Lithos 265, 138-147 (2016).

20. Thomson, A. R. et al. Origin of sub-lithospheric diamonds from the Juina-5 kimberlite (Brazil): Constraints from carbon isotopes and inclusion compositions. Contributions to Mineralogy and Petrology 168, 1081 (2014).

21. Bulanova, G. P. et al. Mineral inclusions in sublithospheric diamonds from Collier 4 kimberlite pipe, Juina, Brazil: Subducted protoliths, carbonated melts and primary kimberlite magmatism. Contributions to Mineralogy and Petrology 160, 489-510 (2010).

22. Beyer, C. \& Frost, D. J. The depth of sub-lithospheric diamond formation and the redistribution of carbon in the deep mantle. Earth and Planetary Science Letters 461, 30-39 (2017).

23. Pearson, D. G. et al. Hydrous mantle transition zone indicated by ringwoodite included within diamond. Nature 507, 221-224 (2014).

24. Walter, M. J. et al. Deep mantle cycling of oceanic crust: Evidence from diamonds and their mineral inclusions. Science 334, 54-57 (2011).

25. Nestola, F. et al. $\mathrm{CaSiO}_{3}$ perovskite in diamond indicates the recycling of oceanic crust into the lower mantle. Nature 555, 237-241 (2018).

26. Nestola, F. et al. Olivine with diamond-imposed morphology included in diamonds: Syngenesis or protogenesis? International Geology Review 56, 1658-1667 (2014).

27. Milani, S., Nestola, F., Angel, R. J., Nimis, P. \& Harris, J. W. Crystallographic orientations of olivine inclusions in diamonds. Lithos 265, 312-316 (2016).

28. Nimis, P. Trapped minerals under stress. Geology 46, 287-288 (2018).

29. Angel, R. J., Mazzucchelli, M. L., Alvaro, M. \& Nestola, F. EosFit-Pinc: A simple GUI for host-inclusion elastic thermobarometry. American Mineralogist 102, 1957-1960 (2017).

30. Mazzucchelli, M. L. et al. Elastic geothermobarometry: Corrections for the geometry of the host-inclusion system. Geology 46, 231-234 (2018).

31. Anzolini, C. et al. Depth of formation of super-deep diamonds: Raman barometry of $\mathrm{CaSiO}_{3}$-walstromite inclusions. American Mineralogist 103, 69-74 (2018).

32. Nimis, P. et al. First evidence of hydrous silicic fluid films around solid inclusions in gem quality diamonds. Lithos 260, 384-389 (2016).

33. Taylor, W. R., Jaques, A. L. \& Ridd, M. Nitrogen-defect aggregation characteristics of some Australasian diamonds: Time-temperature constraints on the source regions of pipe and alluvial diamonds. American Mineralogist 75, 1290-1310 (1990).

34. Howell, D. et al. $\mu$-FTIR mapping: Distribution of impurities in different types of diamond growth. Diamond and Related Materials 29, 29-36 (2012).

35. Spetsius, Z. V., Bogush, I. N. \& Kovalchuk, O. E. FTIR mapping of diamond plates of eclogitic and peridtotitc xenoliths from the Nyurinskaya pipe, Yakutia: Genetic implications. Russian Geology and Geophysics 56, 344-353 (2015). 
36. Kohn, S. C., Speich, L., Smith, C. B. \& Bulanova, G. P. FTIR thermochronometry of natural diamonds: A closer look. Lithos 265, 148-158 (2016).

37. Speich, L., Kohn, S. C., Wirth, R., Bulanova, G. P. \& Smith, C. B. The relationship between platelet size and the $\mathrm{B}^{\prime}$ infrared peak of natural diamonds revisited. Lithos 278-281, 419-426 (2017).

38. Speich, L., Kohn, S. C., Bulanova, G. P. \& Smith, C. B. The behaviour of platelets in natural diamonds and the development of a new mantle thermometer. Contributions to Mineralogy and Petrology 173, 39 (2018).

39. Smit, K. V., D’Haenens-Johansson, U. F. S., Howell, D., Loudin, L. C. \& Wang, W. Deformation-related spectroscopic features in natural Type Ib-IaA diamonds from Zimmi (West African craton). Mineralogy and Petrology 69, 1-15 (2018).

40. Smit, K. V., Shirey, S. B., Stern, R. A., Steele, A. \& Wang, W. Diamond growth from $\mathrm{C}-\mathrm{H}-\mathrm{N}-\mathrm{O}$ recycled fluids in the lithosphere; evidence from $\mathrm{CH}_{4}$ microinclusions and delta ${ }^{13} \mathrm{C}$-delta ${ }^{15} \mathrm{~N}-\mathrm{N}$ content in Marange mixed-habit diamonds. Lithos 265, 68-81 (2016).

41. Frost, D. J. \& McCammon, C. A. The redox state of Earth's mantle. Annual Reviews of Earth Planetaary Science 36, 389-420 (2008).

42. Eggler, D. H. \& Baker, D. R. Reduced volatiles in the system C O H: Implications to mantle melting, fluid formation, and diamond genesis. In Advances in Earth and planetary sciences: Vol. 12, high pressure research in geophysics (eds. S. Akimoto \& M. H. Manghnani) 237-250 (Kluwer, 1982).

43. Green, D. H., Falloon, T. J. \& Taylor, W. R. Mantle-derived magmas - Roles of variable source peridotite and variable $\mathrm{C}-\mathrm{H}-\mathrm{O}$ fluid compositions. In Magmatic processes: Physiochemical principles (ed. B. O. Mysen) 139-154 (The Geochemical Society, 1987).

44. Matveev, S., Ballhaus, C., Fricke, K., Truckenbrodt, J. \& Ziegenben, D. Volatiles in the Earth's mantle: I. Synthesis of CHO fluids at $1273 \mathrm{~K}$ and $2.4 \mathrm{GPa}$. Geochimica et Cosmchimica Acta 61, 3081-3088 (1997).

45. Zhang, C. \& Duan, Z. A model for C-O-H fluid in the Earth's mantle. Geochimica et Cosmochimica Acta 73, 2089-2102 (2009).

46. Stagno, V., Ojwang, D. O., McCammon, C. A. \& Frost, D. J. The oxidation state of the mantle and the extraction of carbon from Earth's interior. Nature 493, 84-88 (2013).

47. Luth, R. W. \& Stachel, T. The buffering capacity of lithospheric mantle; implications for diamond formation. Contributions to Mineralogy and Petrology 168, 1-12 (2014).

48. Stachel, T., Harris, J. W. \& Muehlenbachs, K. Sources of carbon in inclusion bearing diamonds. Lithos 112, 625-637 (2009).

49. Smith, E. M. et al. Large gem diamonds from metallic liquid in Earth's deep mantle. Science 354, 1403-1405 (2016).

50. Scott, H. P. et al. Generation of methane in the Earth's mantle: In situ, high pressuretemperature measurements of carbonate reduction. Proceedings of the National Academy of Sciences 101, 14023-14026 (2004).

51. Stachel, T., Chacko, T. \& Luth, R. W. Carbon isotope fractionation during diamond growth in depleted peridotite; counterintuitive insights from modelling watermaximum $\mathrm{CHO}$ fluids as multi-component systems. Earth and Planetary Science Letters 473, 44-51 (2017).

52. Petts, D. C., Chacko, T., Stachel, T., Stern, R. A. \& Heaman, L. M. A nitrogen isotope fractionation factor between diamond and its parental fluid derived from 
detailed SIMS analysis of a gem diamond and theoretical calculations. Chemical Geology 410, 188-200 (2015).

53. Wyllie, P. J. Metasomatism and fluid generation in mantle xenoliths. In Mantle xenoliths (ed. P. H. Nixon) 609-621 (John Wiley and Sons, 1987).

54. Taylor, W. R. \& Green, D. H. Measurement of reduced peridotite-C-O-H solidus and implications for redox melting of the mantle. Nature 332, 349-352 (1988).

55. Thomassot, E., Cartigny, P., Harris, J. W. \& Viljoen, K. S. Methane-related diamond crystallization in the Earth's mantle; stable isotope evidences from a single diamondbearing xenolith. Earth and Planetary Science Letters 257, 362-371 (2007).

56. Walter, M. J. et al. Primary carbonatite melt from deeply subducted oceanic crust. Nature 454, 622-625 (2008).

57. Thomson, A. R., Walter, M. J., Kohn, S. C. \& Brooker, R. A. Slab melting as a barrier to deep carbon subduction. Nature 529, 76-79 (2016).

58. Stachel, T. \& Luth, R. W. Diamond formation; where, when and how? Lithos 220223, 200-220 (2015).

59. Hasterok, D. \& Chapman, D. S. Heat production and geotherms for the continental lithosphere. Earth and Planetary Science Letters 307, 59-70 (2011).

60. Ray, J. S. \& Ramesh, R. Rayleigh fractionation of stable isotopes from a multicomponent source. Geochimica et Cosmochimica Acta 64, 299-306 (2000).

61. Navon, O., Hutcheon, I. D., Rossman, G. R. \& Wasserburg, G. J. Mantle-derived fluids in diamond micro-inclusions. Nature 335, 784-789 (1988).

62. Weiss, Y. et al. A new model for the evolution of diamond-forming fluids; evidence from microinclusion-bearing diamonds from Kankan, Guinea. Lithos 112, 660-674 (2009).

63. Tomlinson, E. L. \& Mueller, W. A snapshot of mantle metasomatism; trace element analysis of coexisting fluid (LA-ICP-MS) and silicate (SIMS) inclusions in fibrous diamonds. Earth and Planetary Science Letters 279, 362-372 (2009).

64. Weiss, Y., Griffin, W. L. \& Navon, O. Diamond-forming fluids in fibrous diamonds; The trace-element perspective. Earth and Planetary Science Letters 376, 110-125 (2013).

65. Klein-Bendavid, O. et al. The sources and time-integrated evolution of diamondforming fluids - Trace elements and isotopic evidence. Geochimica et Cosmchimica Acta 125, 146-169 (2014).

66. Weiss, Y., Griffin, W. L., Bell, D. R. \& Navon, O. High-Mg carbonatitic melts in diamonds, kimberlites and the sub-continental lithosphere. Earth and Planetary Science Letters 309, 337-347 (2011).

67. Elazar, O., Navon, O. \& Kessel, R. Melting of hydrous-carbonated eclogite at 4-6 $\mathrm{GPa}$ and $900-1200^{\circ} \mathrm{C}$ : Implications for the sources of diamond-forming fluids. 11th International Kimberlite Conference Extended Abstract, No. 11IKC-4471 (2017).

68. Weiss, Y., McNeill, J., Pearson, D. G., Nowell, G. M. \& Ottley, C. J. Highly saline fluids form a subducting slab as the source for fluid-rich diamonds. Nature 524, 339-342 (2015).

69. Weiss, Y., Navon, O., Goldstein, S. L. \& Harris, J. W. Inclusions in diamonds constrain thermo-chemical conditions during Mesozoic metasomatism of the Kaapvaal cratonic mantle. Earth and Planetary Science Letters 491, 134-147 (2018).

70. Izraeli, E. S., Harris, J. W. \& Navon, O. Brine inclusions in diamonds; a new upper mantle fluid. Earth and Planetary Science Letters 187, 323-332 (2001).

71. Shiryaev, A. A. et al. Chemical, optical and isotopic investigation of fibrous diamonds from Brazil. Russian Geology and Geophysics 46, 1185-1201 (2005). 
72. Klein-BenDavid, O., Pearson, D. G., Nowell, G. M., Ottley, C. \& Cartigny, P. Origins of diamond forming fluids; constraints from a coupled $\mathrm{Sr}-\mathrm{Nd}-\mathrm{Pb}$ isotope and trace element approach. Abstracts - Israel Geological Society, Annual Meeting 2009, 75 (2009).

73. Klein-BenDavid, O., Wirth, R. \& Navon, O. Micrometer-scale cavities in fibrous and cloudy diamonds; a glance into diamond dissolution events. Earth and Planetary Science Letters 264, 89-103 (2007).

74. Schrauder, M. \& Navon, O. Solid carbon dioxide in a natural diamond. Nature $\mathbf{3 6 5}$, 42-44 (1993).

75. Tomlinson, E. L., Jones, A. P. \& Harris, J. W. Co-existing fluid and silicate inclusions in mantle diamond. Earth and Planetary Science Letters 250, 581-595 (2006).

76. Smith, E. M., Kopylova, M. G., Nowell, G. M., Pearson, D. G. \& Ryder, J. Archean mantle fluids preserved in fibrous diamonds from Wawa, Superior Craton. Geology 40, 1071-1074 (2012).

77. Weiss, Y., Kiflawi, I., Davies, N. \& Navon, O. High density fluids and the growth of monocrystalline diamonds. Geochimica et Cosmochimica Acta 141, 145-159 (2014).

78. Jablon, B. M. \& Navon, O. Most diamonds were created equal. Earth and Planetary Science Letters 443, 41-47 (2016).

79. Zedgenizov, D. A. et al. Directional chemical variations in diamonds showing octahedral following cuboid growth. Contributions to Mineralogy and Petrology 151, 45-57 (2006).

80. Shirey, S. B., Richardson, S. H. \& Harris, J. W. Integrated models of diamond formation and craton evolution. Lithos 77, 923-944 (2004).

81. Cartigny, P., Palot, M., Thomassot, E. \& Harris, J. W. Diamond formation; a stable isotope perspective. Annual Review of Earth and Planetary Sciences 42, 699-732 (2014).

82. Huang, J. et al. Magnesium and oxygen isotopes in Roberts Victor eclogites. Chemical Geology 438, 73-83 (2016).

83. Farquhar, J. et al. Mass-independent sulfur of inclusions in diamond and sulfur recycling on early Earth. Science 298, 2369-2372 (2002).

84. Chaussidon, M., Albarede, F. \& Sheppard, S. M. F. Sulfur isotope heterogeneity in the mantle from ion microprobe measurements of sulphide inclusions in diamonds. Nature 330, 242-244 (1987).

85. Eldridge, C. S., Compston, W., Williams, I. S., Harris, J. W. \& Bristow, J. W. Isotope evidence for the involvement of recycled sediments in diamond formation. Nature 353, 649-653 (1991).

86. Thomassot, E. et al. Metasomatic diamond growth; a multi-isotope study $\left({ }^{13} \mathrm{C},{ }^{15} \mathrm{~N}\right.$, ${ }^{33} \mathrm{~S},{ }^{34} \mathrm{~S}$ ) of sulphide inclusions and their host diamonds from Jwaneng (Botswana). Earth and Planetary Science Letters 282, 79-90 (2009).

87. Thomassot, E., O’Neil, J., Francis, D., Cartigny, P. \& Wing, B. A. Atmospheric record in the Hadean Eon from multiple sulfur isotope measurements in Nuvvuagittuq Greenstone Belt (Nunavik, Quebec). Proceedings of the National Academy of Science 112, 707-712 (2015).

88. Cartigny, P. et al. A mantle origin for Paleoarchean peridotitic diamonds from the Panda kimberlite, Slave Craton; evidence from ${ }^{13} \mathrm{C},{ }^{15} \mathrm{~N}$ and ${ }^{33,34} \mathrm{~S}$ stable isotope systematics. Lithos 112, 852-864 (2009).

89. Labidi, J., Cartigny, P., Hamelin, C., Moreira, M. \& Dosso, L. Sulfur isotope budget $\left({ }^{32} \mathrm{~S},{ }^{33} \mathrm{~S},{ }^{34} \mathrm{~S}\right.$ and $\left.{ }^{36} \mathrm{~S}\right)$ in Pacific-Antarctic ridge basalts: A record of mantle source heterogeneity and hydrothermal sulfide assimilation. Geochimica et Cosmchimica Acta 133, 47-67 (2014). 
90. Labidi, J., Cartigny, P. \& Moreira, M. Non-chondritic sulphur isotope composition of the terrestrial mantle. Nature 501, 208-211 (2013).

91. Cabral, R. A. et al. Anomalous sulphur isotopes in plume lavas reveal deep mantle storage of Archaean crust. Nature 496, 490-493 (2013).

92. Delavault, H., Chauvel, C., Thomassot, E., Devey, C. W. \& Dazas, B. Sulfur and lead isotopic evidence of relic Archean sediments in the Pitcairn mantle plume. Proceedings of the National Academy of Sciences 113, 12952-12956 (2016).

93. Ueno, Y., Ono, S., Rumble, D. \& Maruyama, S. Quadruple sulfur isotope analysis of ca. 3.5 Ga Dresser Formation: New evidence for microbial sulfate reduction in the early Archean. Geochimica et Cosmochimica Acta 72, 5675-5691 (2008).

94. Roerdink, D. L., Mason, P. R. D., Whitehouse, M. J. \& Brouwer, F. M. Reworking of atmospheric sulfur in a Paleoarchean hydrothermal system at Londozi, Barberton Greenstone Belt, Swaziland. Precambrian Research 280, 195-204 (2016).

95. Farquhar, J. \& Jackson, M. Missing Archean sulfur returned from the mantle. Proceedings of the National Academy of Science 113, 12893-12895 (2016).

96. Ono, S., Wing, B., Johnston, D. \& Farquhar, J. Mass-dependent fractionation of quadruple stable sulfur isotope system as a new tracer of sulfur biogeochemical cycles. Geochimica et Cosmchimica Acta 70, 2238-2252 (2006).

97. Moore, R. O. \& Gurney, J. J. Pyroxene solid solution in garnets included in diamond. Nature 318, 553-555 (1985).

98. Stachel, T., Harris, J. W., Brey, G. P. \& Joswig, W. Kankan diamonds (Guinea) II: Lower mantle inclusion parageneses. Contributions to Mineralogy and Petrology 140, 16-27 (2000).

99. Hutchison, M. T., Cartigny, P. \& Harris, J. W. Carbon and nitrogen compositions and physical characteristics of transition zone and lower mantle diamonds from Sao Luiz, Brazil. In The J. B. Dawson volume; Proceedings of the VIIth International Kimberlite Conference; Vol. 1. (eds. J. J. Gurney, J. L. Gurney, M. D. Pascoe \& S. H. Richardson) 372-382 (1999).

100. Kaminsky, F. V. et al. Superdeep diamonds form the Juina area, Mato Grosso State, Brazil. Contributions to Mineralogy and Petrology 140, 734-753 (2001).

101. Palot, M., Cartigny, P., Harris, J. W., Kaminsky, F. V. \& Stachel, T. Evidence for deep mantle convection and primordial heterogeneity from nitrogen and carbon stable isotopes in diamond. Earth and Planetary Science Letters 357-358, 179-193 (2012).

102. Zedgenizov, D. A., Kagi, H., Shatsky, V. S. \& Ragozin, A. L. Local variations of carbon isotope composition in diamonds from Sao Luis (Brazil); evidence for heterogenous carbon reservoir in sublithospheric mantle. Chemical Geology 363, 114-124 (2014).

103. Burnham, A. D. et al. Diamonds from the Machado River alluvial deposit, Rondonia, Brazil, derived from both lithospheric and sublithospheric mantle. Lithos 265, 199-213 (2016).

104. Burnham, A. D. et al. Stable isotope evidence for crustal recycling as recorded by superdeep diamonds. Earth and Planetary Science Letters 432, 374-380 (2015).

105. Tappert, R. et al. Diamonds from Jagersfontein (South Africa); messengers from the sublithospheric mantle. Contributions to Mineralogy and Petrology 150, 505-522 (2005).

106. Palot, M. et al. The transition zone as a host for recycled volatiles: Evidence from nitrogen and carbon isotopes in ultra-deep diamonds from Monastery and Jagersfontein (South Africa). Chemical Geology 466, 733-749 (2017). 
107. Palot, M., Pearson, D. G., Stern, R. A., Stachel, T. \& Harris, J. W. Isotopic constraints on the nature and circulation of deep mantle $\mathrm{C}-\mathrm{H}-\mathrm{O}-\mathrm{N}$ fluids; carbon and nitrogen systematics within ultra-deep diamonds from Kankan (Guinea). Geochimica et Cosmochimica Acta 139, 26-46 (2014).

108. Stachel, T., Harris, J. W., Aulbach, S. \& Deines, P. Kankan diamonds (Guinea) III; delta ${ }^{13} \mathrm{C}$ and nitrogen characteristics of deep diamonds. Contributions to Mineralogy and Petrology 142, 465-475 (2002).

109. Ickert, R. B., Stachel, T., Stern, R. A. \& Harris, J. W. Extreme ${ }^{18}$ O-enrichment in majorite constrains a crustal origin of transition zone diamonds. Geochemical Perspectives Letters 1, 65-74 (2015).

110. Smyth, J. R. $\beta-\mathrm{Mg}_{2} \mathrm{SiO}_{4}$ : A potential host for water in the mantle? American Mineralogist 72, 1051-1055 (1987).

111. Van der Hilst, R. D., Widiyantoro, S. \& Engdahl, E. R. Evidence for deep mantle circulation from global tomography. Nature 386, 578-584 (1997).

112. Kohlstedt, D. L., Keppler, H. \& Rubie, D. C. Solubility of water in the $\alpha, \beta$ and $\gamma$ phases of $(\mathrm{Mg}, \mathrm{Fe})_{2} \mathrm{SiO}_{4}$. Contributions to Mineralogy and Petrology 123, 345-357 (1996).

113. Brenker, F. E. et al. Detection of a Ca-rich lithology in the Earth's deep ( $>300 \mathrm{~km})$ convecting mantle. Earth and Planetary Science Letters 236, 579-587 (2005).

114. Harte, B. \& Hudson, N. F. C. Mineral associations in diamonds from the lowermost upper mantle and uppermost lower mantle. In Proceedings of 10th International Kimberlite Conference (ed. D. G. Pearson) 235-253 (Springer, 2013).

115. Nestola, F. Inclusions in super-deep diamonds: Windows on the very deep Earth. Rendiconti Lincei 28, 595-604 (2017).

116. Brenker, F. E., Stachel, T. \& Harris, J. W. Exhumation of lower mantle inclusions in diamond; ATEM investigation of retrograde phase transitions, reactions and exsolution. Earth and Planetary Science Letters 198, 1-9 (2002).

117. Brey, G. P., Bulatov, V., Girnis, A., Harris, J. W. \& Stachel, T. Ferropericlase A lower mantle phase in the upper mantle. Lithos 77, 655-663 (2004).

118. Hayman, P. C., Kopylova, M. G. \& Kaminsky, F. V. Lower mantle diamonds from Rio Soriso (Juina area, Mato Grosso, Brazil). Contributions to Mineralogy and Petrology 149, 430-445 (2005).

119. Thomas, S.-M. et al. Quantification of water in hydrous ringwoodite. Frontiers in Earth Science 2, 38 (2015).

120. Litasov, K. D. \& Ohtani, E. Effect of water on the phase relations in Earth's mantle and deep water cycle. In Advances in high pressure mineralogy (ed. E. Ohtani) 115-156 (Geological Society of America, 2007).

121. Nestola, F. \& Smyth, J. R. Diamonds and water in the deep Earth; a new scenario. International Geology Review 58, 263-276 (2016).

122. Schmandt, B., Jacobsen, S. D., Becker, T. W., Liu, Z. \& Dueker, K. G. Dehydration melting at the top of the lower mantle. Science 344, 1265 (2014).

123. Liu, Z., Park, J. \& Karato, S.-I. Seismic evidence for water transport out of the mantle transition zone beneath the European Alps. Earth and Planetary Science Letters 482, 93-104 (2018).

124. Zhang, Z., Dueker, K. G. \& Huang, H.-H. Ps mantle transition zone imaging beneath the Colorado Rocky Mountains: Evidence for an upwelling hydrous mantle. Earth and Planetary Science Letters 492, 197-205 (2018).

125. Wirth, R., Vollmer, C., Brenker, F., Matsyuk, S. \& Kaminsky, F. Inclusions of nanocrystalline hydrous aluminium silicate "phase egg" in superdeep diamonds from 
Juina (Mato Grosso State, Brazil). Earth and Planetary Science Letters 259, 384-399 (2007).

126. Palot, M. et al. Evidence for $\mathrm{H}_{2} \mathrm{O}$-bearing fluids in the lower mantle from diamond inclusion. Lithos 265, 237-243 (2016).

127. Tschauner, O. et al. Ice-VII inclusions in diamonds: Evidence for aqueous fluid in Earth's deep mantle. Science 359, 1136-1139 (2018).

128. Bundy, F. P., Hall, H. T., Strong, H. M. \& Wentorf Jun, R. H. Man-made diamonds. Nature 176, 51-55 (1955).

129. Arima, M., Nakayama, K., Akaish, M., Yamaoka, S. \& Kanda, H. Crystallization of diamond from a silicate melt of kimberlite composition in high-pressure and hightemperature experiments. Geology 21, 968-970 (1993).

130. Palyanov, Y. N., Sokol, A. G., Borzdov, Y. M., Khokhryakov, A. F. \& Sobolev, N. V. Diamond formation from mantle carbonate fluids. Nature 400, 417-418 (1999).

131. Sokol, A. G., Borzdov, Y. M., Pal'yanov, Y. N., Khokhryakov, A. F. \& Sobolev, N. V. An experimental demonstration of diamond formation in the dolomite-carbon and dolomite-fluid-carbon systems. European Journal of Mineralogy 13, 893-900 (2001).

132. Fagan, A. J. \& Luth, R. W. Growth of diamond in hydrous silicate melts. Contributions to Mineralogy and Petrology 161, 229-236 (2011).

133. Palyanov, Y. N., Sokol, A. G., Khokhryakov, A. F. \& Kruk, A. N. Conditions of diamond crystallization in kimblerlite melt: Experimental data. Russian Geology and Geophysics 36, 196-210 (2015).

134. Litvin, Y. A. \& Butvina, V. G. Diamond-forming media in the system eclogitecarbonatite-sulfide-carbon: Experiments at 6.0-8.5 GPa. Petrology 12, 377-387 (2004).

135. Sokol, A. G. \& Palyanov, Y. N. Diamond formation in the system $\mathrm{MgO}-\mathrm{SiO}_{2}-\mathrm{H}_{2} \mathrm{O}-$ $\mathrm{C}$ at $7.5 \mathrm{GPa}$ and $1,600^{\circ} \mathrm{C}$. Contributions to Mineralogy and Petrology 155, 33-43 (2008).

136. Bureau, H. et al. Diamond growth in mantle fluids. Lithos 265, 4-15 (2016).

137. Bureau, H. et al. The growth of fibrous, cloudy and polycrystalline diamonds. Geochimica et Cosmochimica Acta 77, 202-214 (2012).

138. Sokol, A. G., Palyanova, G. A., Palyanov, Y. N., Tomilenko, A. A. \& Melenevskiy, V. N. Fluid regime and diamond formation in the reduced mantle; experimental constraints. Geochimica et Cosmochimica Acta 73, 5820-5834 (2009).

139. Palyanov, Y. N. \& Sokol, A. G. The effect of composition of mantle fluids/melts on diamond formation processes. Lithos 112, 690-700 (2009).

140. Novella, D., Bolfan-Casanova, N., Nestola, F. \& Harris, J. W. $\mathrm{H}_{2} \mathrm{O}$ in olivine and garnet inclusions still trapped in diamonds from the Siberian Craton; implications for the water content of cratonic lithosphere peridotites. Lithos 230, 180-183 (2015).

141. Bataleva, Y. V., Palyanov, Y. N., Borzdov, Y. M., Kupriyanov, I. N. \& Sokol, A. G. Synthesis of diamonds with mineral, fluid and melt inclusions. Lithos 265, 292-303 (2016).

142. Rohrbach, A. \& Schmidt, M. W. Redox freezing and melting in the Earth's deep mantle resulting from carbon-iron redox coupling. Nature 472, 209-214 (2011).

143. Palyanov, Y. N. et al. Mantle-slab interaction and redox mechanism of diamond formation. Proceedings of the National Academy of Sciences 110, 20408-20413 (2013). 
144. Gurney, J. J., Harris, J. W. \& Rickard, R. S. Silicate and oxide inclusions in diamonds from the Orapa Mine, Botswana. In Developments in petrology, Vol. 11 (ed. J. Kornprobst) 3-9 (Elsevier, 1984).

145. Orlov, Y. L. The mineralogy of the diamond (John Wiley and Sons, 1977).

146. Dobosi, G. \& Kurat, G. On the origin of silicate-bearing diamondites. Mineralogy and Petrology 99, 29-42 (2010).

147. Rubanova, E. V., Piazolo, S., Griffin, W. L. \& O'Reilly, S. Y. Deformation microstructures reveal a complex mantle history for polycrystalline diamond. Geochemistry Geophysics Geosystems 13, Q10010 (2012).

148. Jacob, D. E., Piazolo, S., Schreiber, A. \& Trimby, P. Redox-freezing and nucleation of diamond via magnetite formation in the Earth's mantle. Nature Communications 21, 7 (2016).

149. Jacob, D. E., Viljoen, K. S., Grassineau, N. \& Jagoutz, E. Remobilization in the cratonic lithosphere recorded in polycrystalline diamond. Science 289, 1182-1185 (2000).

150. Jacob, D. E., Kronz, A. \& Viljoen, K. S. Cohenite, native iron and troilite inclusions in garnets from polycrystalline diamond aggregates. Contributions to Mineralogy and Petrology 146, 566-576 (2004).

151. Mikhail, S. et al. Constraining the internal variability of the stable isotopes of carbon and nitrogen within mantle diamonds. Chemical Geology 366, 14-23 (2014).

152. Mikhail, S., Dobosi, G., Verchovsky, A. B., Kurat, G. \& Jones, A. P. Peridotitic and websteritic diamondites provide new information regarding mantle melting and metasomatism induced through the subduction of crustal volatiles. Geochimica et Cosmchimica Acta 107, 1-11 (2013).

153. Jacob, D. E., Dobrzhinetskaya, L. \& Wirth, R. New insight into polycrystalline diamond genesis from modern nanoanalytical techniques. Earth-Science Reviews 136, 21-35 (2014).

154. Gautheron, C., Cartigny, P., Moreira, M., Harris, J. W. \& Allegre, C. J. Evidence for a mantle component shown by rare gases, $\mathrm{C}$ and $\mathrm{N}$ isotopes in polycrystalline diamonds from Orapa (Botswana). Earth and Planetary Science Letters 240, 559-572 (2005).

155. Mikhail, S., Howell, D. \& McCubbin, F. M. Evidence for multiple diamonditeforming events in the mantle. American Mineralogist 99, 1537-1543 (2014).

156. Maruoka, T., Kurat, G., Dobosi, G. \& Koeberl, C. Isotopic composition of carbon in diamonds of diamondites: Record of mass fractionation in the upper mantle. Geochimica et Cosmchimica Acta 68, 1635-1644 (2004).

157. Foley, S. F. \& Fischer, T. P. An essential role for continental rifts and lithosphere in the deep carbon cycle. Nature Geoscience 10, 897-902 (2017).

158. Stagno, V. \& Frost, D. J. Carbon speciation in the asthenosphere: Experimental measurements of the redox conditions at which carbonate-bearing melts coexist with graphite or diamond in peridotite assemblages. Earth and Planetary Science Letters 300, 72-84 (2010).

159. Kjarsgaard, B. A., Heaman, L. M., Sarkar, C. \& Pearson, D. G. The North America mid-Cretaceous kimberlite corridor: Wet, edge-driven decompression melting of an OIB-type deep mantle source. Geochemistry Geophysics Geosystems 18, 2727-2747 (2017).

160. Tappe, S., Smart, K., Torsvik, T., Massuyeau, M. \& de Wit, M. Geodynamics of kimberlites on a cooling Earth: Clues to plate tectonic evolution and deep volatile cycles. Earth and Planetary Science Letters 484, 1-14 (2018). 
161. Smit, K. V., Shirey, S. B., Richardson, S. H., le Roex, A. P. \& Gurney, J. J. Re-Os isotopic composition of peridotitic sulphide inclusions in diamonds from Ellendale, Australia: Age constraints on Kimberley cratonic lithosphere. Geochimica et Cosmochimica Acta 74, 3292-3306, (2010).

162. de Vries, D. F. W. et al. Re-Os dating of sulphide inclusions zonally distributed in single Yakutian diamonds: Evidence for multiple episodes of Proterozoic formation and protracted timescales of diamond growth. Geochimica et Cosmochimica Acta 120, 363-394 (2013).

163. Koornneef, J. M. et al. Archaean and Proterozoic diamond growth from contrasting styles of large-scale magmatism. Nature Communications 8, 648 (2017).

164. Aulbach, S. et al. Diamond ages from Victor (Superior Craton): Intra-mantle cycling of volatiles $(\mathrm{C}, \mathrm{N}, \mathrm{S})$ during supercontinent reorganisation. Earth and Planetary Science Letters 490, 77-87 (2018).

165. Griffin, W. L. et al. The world turns over: Hadean-Archean crust-mantle evolution. Lithos 189, 2-15 (2014).

166. Ionov, D. A., Carlson, R. W., Doucet, L. S., Golovin, A. V. \& Oleinikov, O. B. The age and history of the lithospheric mantle of the Siberian craton: Re-Os and PGE study of peridotite xenoliths from the Obnazhennaya kimberlite. Earth and Planetary Science Letters 428, 108-119 (2015).

167. Yaxley, G. M., Berry, A. J., Rosenthal, A., Woodland, A. B. \& Paterson, D. Redox preconditioning deep cratonic lithosphere for kimberlite genesis - evidence from the central Slave Craton. Scientific Reports 7, 30 (2017).

168. Giuliani, A. et al. Petrogenesis of mantle polymict breccias: Insights into mantle processes coeval with kimberlite magmatism. Journal of Petrology 55, 831-858 (2014).

169. Aulbach, S. Craton nucleation and formation of thick lithospheric roots. Lithos 149, 16-30 (2012).

170. McCammon, C. A., Griffin, W. L., Shee, S. R. \& O’Neill, H. S. C. Oxidation during metasomatism in ultramafic xenoliths from the Wesselton kimberlite, South Africa: Implications for the survival of diamond. Contributions to Mineralogy and Petrology 141, 287-296 (2001).

171. Creighton, S. et al. Oxidation of the Kaapvaal lithospheric mantle driven by metasomatism. Contributions to Mineralogy and Petrology 157, 491-504 (2009).

172. Aulbach, S., Griffin, W. L., Pearson, N. J. \& O'Reilly, S. Y. Nature and timing of metasomatism in the stratified mantle lithosphere beneath the central Slave Craton (Canada). Chemical Geology 352, 153-169 (2013).

173. Simon, N. S. C., Irvine, G. J., Davies, G. R., Pearson, D. G. \& Carlson, R. W. The origin of garnet and clinopyroxene in "depleted" Kaapvaal peridotites. Lithos 71, 289-322 (2003).

174. Wang, W., Gasparik, T. \& Rapp, R. P. Partitioning of rare earth elements between $\mathrm{CaSiO}_{3}$ perovskite and coexisting phases; constraints on the formation of $\mathrm{CaSiO}_{3}$ inclusions in diamonds. Earth and Planetary Science Letters 181, 291-300 (2000).

175. Brenker, F. E. et al. Carbonates from the lower part of transition zone or even the lower mantle. Earth and Planetary Science Letters 260, 1-9 (2007).

176. Thomson, A. R. et al. Trace element composition of silicate inclusions in sublithospheric diamonds from the Juina-5 kimberlite; evidence for diamond growth from slab melts. Lithos 265, 108-124 (2016).

177. Harte, B. \& Cayzer, N. Decompression and unmixing of crystals included in diamonds from the mantle transition zone. Physics and Chemistry of Minerals 34, 647-656 (2007). 
178. Stachel, T., Brey, G. P. \& Harris, J. W. Kankan diamonds (Guinea) I: From the lithosphere down to the transition zone. Contributions to Mineralogy and Petrology 140, 1-15 (2000).

179. Kiseeva, E. S., Litasov, K. D., Yaxley, G. M., Ohtani, E. \& Kamenetsky, V. S. Melting and phase relations of carbonated eclogite at 9-21 GPa and the petrogenesis of alkali-rich melts in the deep mantle. Journal of Petrology 54, 1555-1583 (2013).

180. Davies, R. M., Griffin, W. L., O’Reilly, S. Y. \& McCandless, T. E. Inclusions in diamonds from the K14 and K10 kimberlites, Buffalo Hills, Alberta, Canada; diamond growth in a plume? Lithos 77, 99-111 (2004).

181. Hutchison, M. T. Constitution of the deep transition zone and lower mantle shown by diamonds and their inclusions (University of Edinburgh, 1997).

182. Moore, R. O., Gurney, J. J., Griffin, W. L. \& Shimizu, N. Ultra-high pressure garnet inclusions in Monastery diamonds: Trace element abundance patterns and conditions of origin. European Journal of Mineralogy 3, 213-230 (1991).

183. Syracuse, E. M. et al. The global range of subduction zone thermal models. Physics of the Earth and Planetary Interiors 183, 73-90 (2010).

184. Moore, R. O. \& Gurney, J. J. Mineral inclusions in diamond from the Monastry kimberlite, South Africa. In Kimberlites and related rocks, Vol. 14 (eds. J. Ross et al.) 1029-1041 (Geological Society of Australia, 1989).

185. Wilding, M., Harte, B. \& Harris, J. W. Carbon isotope variation in a zoned Bultfontein diamond determined by SIMS. In Seventh International Conference on Geochronology, Cosmochronology and Isotope Geology; abstracts volume, Vol. 27 (ed. W. Compston) 112 (Geological Society of Australia, 1990).

186. Beyer, C., Frost, D. J. \& Miyajimas, N. Experimental calibration of a garnetclinopyroxene geobarometer for mantle eclogites. Contributions to Mineralogy and Petrology 169, 18 (2015).

187. Armstrong, L. S. et al. Perovskite phase relations in the system $\mathrm{CaO}-\mathrm{MgO}-\mathrm{TiO}_{2}-$ $\mathrm{SiO}_{2}$ and implications for deep mantle lithologies. Journal of Petrology 53, 611-635 (2012).

188. Kubo, A., Suzuki, T. \& Akaogi, M. High pressure phase equilibria in the system $\mathrm{CaTiO}_{3}-\mathrm{CaSiO}_{3}$ : Stability of perovskite solid solutions. Physics and Chemistry of Minerals 24, 488-494 (1997).

189. Zedgenizov, D. A., Ragozin, A. L., Kalinina, V. V. \& Kagi, H. The mineralogy of Ca-rich inclusions in sublithospheric diamonds. Geochemistry International 54, 890-900 (2016).

190. Kiseeva, E. S., Wood, B. J., Ghosh, S. \& Stachel, T. The pyroxenite-diamond connection. Geochemical Perspectives Letters 2, 1-9 (2016).

191. Kaminsky, F. V. et al. Oxidation potential in the Earth's lower mantle as recorded by ferropericlase inclusions in diamond. Earth and Planetary Science Letters 417, 49-56 (2015).

192. Smith, E. M., Shirey, S. B. \& Wang, W. The very deep origin of the world's biggest diamonds. Gems and Gemology 53, 388-403 (2017).

193. Moore, A. E. The origin of large irregular gem-quality Type II diamonds and the rarity of blue Type IIB varieties. South African Journal of Geology 117, 219-236 (2014).

194. Bowen, D. C., Ferraris, R. D., Palmer, C. E. \& Ward, J. D. On the unusual characteristics of the diamonds from Letseng-la-Terae kimberlites, Lesotho. Lithos 112, 767-774 (2009). 
195. Brenker, F. et al. Detection of a Ca-rich lithology in the Earth's deep (>300 km) convecting mantle. Earth and Planetary Science Letters 236, 579-587 (2005).

196. Wijbrans, C. H., Rohrbach, A. \& Klemme, S. An experimental investigation of the stability of majoritic garnet in the Earth's mantle and an improved majorite geobarometer. Contributions to Mineralogy and Petrology 171, 50 (2016).

197. Bell, P., Mao, H., Weeks, R. \& Valkenburg, A. High pressure disproportionation study of iron in synthetic basalt glass. Carnegie Institution of Washington Yearbook 75, 515-520 (1976).

198. Frost, D. J. et al. Experimental evidence for the existence of iron-rich metal in the Earth's lower mantle. Nature 428, 409-412 (2004).

199. Rohrbach, A. et al. Metal saturation in the upper mantle. Nature 449, 456-458 (2007).

200. Ballhaus, C. Is the upper mantle metal-saturated? Earth and Planetary Science Letters 132, 75-86 (1995). 